\title{
विश्व शान्तिको मुहान लुम्बिनी : प्राचीनता र विकास
}

डा. बद्रीनारायण गौतम*

\section{शोधसार}

प्राचीन मानवीय सभ्यतास्थलका रूपमा चिनिने नेपाल अत्यन्त महत्त्वपूर्ण देवभूमि हो। ब्रहमाण्ड रक्षक भगवान शिवको बासस्थानदेखि मानव मुक्ति-भुक्तिका आधार मानिएका देवस्थल एवं तीर्थस्थलहरूको प्रचुरता रहेको नेपाल अनेकौं महापुरुषहरूको जन्मस्थल-क्रिडास्थल प्रमाणित भइसकेको छ। विश्व जगत्मा धार्मिक कान्ति शुरु भएर कन्फुसियस, लाओत्से, इम्पेडोक्लस आदि दार्शानिकहरूको जन्म भई मध्य र मध्यपूर्व एशिया तरंगित भएक अवधिमा नेपालका भूमियुत्र गौतम बुद्धले थालेको धार्मिक सुधार अभियानले नयाँ धर्म-दर्शन नै स्थापना गर्ने परिस्थिति विकास भयो। सार्वभौम धर्मका रूपमा स्थापित हिन्दू धर्ममा यौन देखि योगसम्म, व्याकरणदेखि सृष्टिसम्म, उत्पादनदेखि राष्ट्र हुँदै सभा, समिति, सौरमण्डल आदि सबैको सिद्धान्त रहेको स्थितिले गर्दा जति पटक लय (विनास) भएपनि पज्चतत्त्वमा विद्यमान त्रिगुण रहुन्जेल सृष्टिक्रम निरन्तर चलिरहने विश्वास व्याप्त थियो। ब्रहमचर्य, गृहस्थ, वानप्रस्थ र सन्यास नामका चार आश्रमहरूको व्यवस्था गरिएको हिन्दू दर्शनले ब्रहमचर्यालाई तपश्या अर्थात् ज्ञानको चरण र गृहस्थलाई उत्पादनको मुल केन्द्रसंगै वैदिक मान्यताको मियो नै ठानेको छ। भौतिकताभन्दा अध्यात्मको यात्राका रूपमा वानप्रस्थलाई मानेर सन्यासलाई लोभ-मोह छाडेर ज्ञानको प्रशारण एवं लोककल्याणसंग जोडेको छ। यसप्रकार ज्ञान र उत्पादनलाई केन्द्रमा राखेको हिन्दू दर्शन निर्देशित वैदिक सनातनको केन्द्ररूपि नेपालमा शैव-शाक्त परम्परामा आधारित शक्ति साधना अर्थात् बलीपूजाको सिद्धान्त अन्तर्गतका सबै संस्कार-संस्कृतिमा नारी अनिवार्य तत्त्व मान्ने धर्म-दर्शन प्रचलित थियो। प्रवृत्ति र निवृत्ति गरी दुइवटा मार्ग रहेको समग्र दर्शन (वैदिक सनातन हिन्दू) अन्तर्गत संसारलाई नै महत्त्वपूर्ण केन्द्र मान्ने सांसारिक ज्ञानलाई प्रवृत्ति मार्गका रूपमा लिइन्छ भने असंसारिक अर्थात् आत्मा परमात्माको चिन्तनलाई मूल मानी संसारलाई मिथ्या ठान्ने मार्गलाई निवृत्ति मार्ग ठहयाइएको छ। त्यसबाट सांसारिक जगत्मा शक्तिशाली र सम्पन्न बन्ने होडबाजी र बलीपूजा लगायतका प्रवृत्तिबाट जाति-वर्ण, धनी-गरिबको विविधता र विभेदपूर्ण स्थिति, राज्य विस्तारको होडबाजी व्याप्त भएको स्थितिमा जन्मिएर सांसारिक जीवन अवलोकनबाटै एक्ल्याएर दु:खको जानकारी नै नपाउने गरि आमोद प्रमोदयुक्त विलाशि जीवनमै भुलाएर हुर्काइएका सिद्धार्थले उनन्तिस वर्षको उमेरमा पुगेपछि मात्र अकस्मात दुःख, जीवन सङ्घर्ष, मृत्यू आदिबारे यथार्थ बोध गर्ने अवसर पाए। त्यसबाट भित्रैदेखि वैराग्य उत्पन्न भएको स्थितिमा माया-मोहको बन्धन त्यागोको सन्यासीलाई प्रशन्न देखेको स्थितिमा माया-मोहको बन्धनवाट उस्कने निश्चय गरेका सिद्धार्थले घरबार त्यागेर ६ वर्षसम्म गरेको अध्ययन-साधनापछि ज्ञान प्राप्त गरि बुद्ध भए। त्यसपछि निवृत्तिमार्ग अर्थात् संसारलाई अनित्य अर्थात् दु:खमय कष्टमय र मायाजालको कारण ठहयाएका उनले मुक्त हुन आह्वान गर्दै पदार्थको गतिशिलतालाई नाशवान मानि मुक्तिका लागि अग्रसर हुन आह्वान गर्दे हिंडे । रिसले वैरभाव शान्त हुँदैन प्रेम भावले मात्र हुन्छ, मानिस विवेकी हुन आफ्नो मूर्खतालाई चिन्नु पर्दछ, जात र वर्गको भावना लिएर कहिल्यै मुक्ति पाइँदैन, स्वर्ग प्राप्तिको

\footnotetext{
* सहप्राध्यापक, नेपाल र एशियाली अनुसन्धान केन्द्र, त्रिभुवन विश्वविद्यालय।
} 
मूल आधार नै अहिंशा र निर्वाण हुन् भन्दै चार आर्य सत्य बोध गरि आर्य अष्टाज़ मार्ग अनुशरणमा जोड दिए। हिंसा जन्य यज्ञ परम्परा रहेको समाजमा संघको अवधारणा ल्याएर हिंसा विरुद्ध उभिएका बुद्ध-जीवन दर्शनको थालनी, महत्त्व, विकासकममाथि केन्द्रित यो लेख राष्ट्रियताको सिद्धान्त-अवधारणामा आधारित रहेर तयार पारिएको छ। समय, स्रोत साधनको कारणले गर्दा द्वितीयक स्रोतसंगै इतिहास-संस्कृतिविद्देखि लुम्बिनी विकासमा संलग्न व्यक्तित्वहरूसँगका अन्तर्वात्तामा आधारित भएर तयार पारिएको यो लेखबाट बौद्ध जन्मस्थल लुम्बिनीको विकासक्रम, महत्त्व र बौद्ध दर्शनको जानकारीमा सघाउ पुग्ने आशा गरिएको छ।

शब्दकुज्जि : मोह-माया र मुक्ति, बौद्ध धर्म-दर्शन, रक्तशुद्धता परम्परा, जनश्रुति र जातक कथाहरू, ऐतिहासिक र पुरातात्त्विक स्थल ।

\section{विषय प्रवेश}

पौराणिककालमै जम्बूद्विप, आर्यावर्त, हिमवत्खण्ड आदि नाम दिइएको नेपाल प्राचीनतम मुलुक हो। हिमवत्खण्ड नेपाल महात्म्य, गण्डकी महात्म्य, पशुपतिपुराण, स्कन्दपुराण, अथर्ववेद परिशिष्ट, वराहपुराण आदि हिन्दू पौराणिक साहित्य, कौटिल्यको अर्थशास्त्र, कल्हणको राजतरंगिणि, चीनको ताङ वृतान्त आदिग्रन्थदेखि स्वयम्भू पराण, मूल सर्वास्तिवाद विनयसड्ग्रह जस्ता बौद्ध ग्रन्थहरूमा भेटिने नेपाल सम्बन्धी चर्चा र वर्णनबाट प्राचीनतम महत्त्वपूर्ण मुलुक भएको स्पष्ट हुन्छ। भारतवर्षकै सवैभन्दा पवित्र र पुण्यमय प्रदेश नेपाल सदैव प्राकृतिक सौन्दर्यताले भरि पूर्ण हिमाली हावापानी एवं जलप्रवाहको प्रचुरतायुक्त रमणिय संगस्थल बनेको छ। प्रकृतिदेवीले आफ़्नै हातले सजाएर अलौकिक सुन्दरताले भरिपूर्ण बनाएको नेपाल प्राचीनतम सभ्यता-संस्कृतिको उदय क्षेत्र हो । पृथ्वी निर्माणक्रममा उत्पन्न भौगर्भिक उथलपुथलले टेथिस सागर क्षेत्रमा हलचल ल्याएपछि, त्यहाँको भूभाग अग्लने र होचिने ऋम शुरु भएर पर्वत-हिमश्रृड्खला बनेपछि खोला नाला, फाँट बेंसी, वन जड्गल, उपत्यका मैदान उत्पत्ती भएर मानव बसोबासयोग्य भूमिमा परिणत भएको हो। विश्वकै सर्वोच्च शिखर सगरमाथादेखि संसारकै होचो भूभाग मुसहर्निया र केचनाकवल समाहित नेपालको १,४१,००० वर्ग किलो मिटर क्षेत्रमा हिमाली, पहाडी, तराई प्रदेश, प्रसिद्ध खोच एवं गल्छीहरू, सुरम्य उपत्यका एवं ताल तलैयाहरू, निरन्तर प्रवाहित नदिहरू र हिममरुस्थलकै कल्को दिने स्थलहरू रहेकाले प्रसिद्धिको उच्च शिखरमा पुगेको देश वा क्षेत्रका रूपमा चिनिन्छ।

प्रागितिहासकालदेखि नै स्वतन्त्र राज्यको अस्तित्त्व कायम गरेको नेपाल उत्तरमा तिब्बतको बलौटे पठारदेखि दक्षिणतर्फ भागिरथी गंगाको विशाल समथर मैदानबीच अवस्थित छ। सभ्यताको आरम्भिक चरणदेखि नै नेपालकै रूपमा रहेको यथार्थलाई अथर्व परिशिष्टमा कामरूप, बिदेह, उदुम्बर, अवन्ती, कैकेय, आदि देशहरूसंगै नेपालको चर्चा गरेको प्रसड्ज, भगवान बुद्धकै समयमा उनका चेलाहरू व्यापारिका साथ नेपाल प्रवेश गरेको विषयमा बौद्धग्रन्थ विनयसड्ग्रहमा गरिएको चर्चासँगै महाभारत-जैन ग्रन्थमा आउने नेपाल प्रसझ्ग आदिले नै पुष्टि गरिसकेका छन् (गौतम, जुलाइ-सेप्टेम्बर २०१९ : द२)। सत्ययुगमा सत्यवती, त्रेतायुगमा तपोवन, द्वापरयुगमा मुक्तिसोपान र कलियुगमा नेपाल नामले चिनिने भूखण्ड भनी हिमवत् खण्डमा उल्लेख गरिएको विषयवस्तुहरू समेतका आधारमा यो देश शुरुदेखि नै हिन्दू धर्म दर्शनको केन्द्र रहेको किटान गरेको पाइन्छ (नाथ, २०१५ : 
२१५- ३७१; पाण्डे र रेग्मी, १९९६ : ७१)। विश्वकै सर्वोच्च शिखर सगरमाथाको देश, विविधताको देश, तेस्रो ध्रुवको देश, जातिय-साँस्कृतिक अनेकताभित्र सामाजिक सद्भाव-एकता रहेको देश आदि विभिन्न उपाधिहरूद्वारा विभूषित हिमाली राष्ट्र नेपाल पौराणिककालदेखि नै प्रसिद्धिको उच्च शिखरमा पुगेको क्षेत्र हो । व्यास, कपिल, पाणिनी, वाल्मिकी, गौतम, ऋष्यत्रहु, विश्वामित्र, याज्ञवल्क्य, भृगु, पुलत्स्य, पुलक आदि विद्वान् तपश्विहरूद्वारा गहन तपसाधनासँगै ज्ञान प्राप्ति, वेद-पुराण-साहित्य सिर्जना गरेको पवित्र भूमिको स्थान पाएको नेपालका पर्वत, शिखर, उपत्यका, गुफा, कन्दरा, वनजड्गल, नदी नाला, गौडा गल्छेडा, करना, ताल आदि सबै सामाजिक साँस्कृतिक विश्वास-प्रवाह अध्ययन अन्वेषण गर्ने साधन पनि हुन सक्दछन् । मानव सभ्यताको उद्भव एवं विकासक्रमदेखि नै मुक्ति-भुक्तिको माध्यम बनेका पवित्र नदीहरूदेखि धर्म दर्शनको केन्द्र बनेका मुक्ति क्षेत्र, वैष्णव क्षेत्र, रुरुक्षेत्र, हरिहरक्षेत्र, वराहक्षेत्र, लुम्बिनीक्षेत्र आदिको अवस्थिति भित्रको यथार्थ अध्ययन गरेमा विभिन्न सभ्यता, संस्कृति, धर्म, वेद, पुराण आदिको उत्पत्ति र विकास स्थल रहेको स्पष्ट हुन्छ। वेदरूपी ज्ञानको मान सरोवरबाट विकसित अनेकौं विचारधाराहरूरूपि दर्शनले आजसम्म पनि विश्वका अनेकौँ राष्ट्रहरूलाई प्रभावित गरिरहेको यथार्थका आधारमा नेपालको प्रसिद्धि र महत्त्व स्पष्ट पार्ने उल्लेखित क्षेत्रहरूको साझ्गोपाड़ चर्चाका लागि विशद अन्वेषणको आवश्यकता पर्ने भएकाले यहाँ विश्व शान्तिका अग्रदूत गौतम बुद्धको जन्मस्थल लुम्बिनी र बौद्ध दर्शनको समिक्षात्मक विश्लेषणमा केन्द्रित हुने प्रयास गरिएको छ। जसबाट गौतम बुद्धको वंश परिचय, बौद्ध दर्शनको चिनारी हुँदै बुद्ध जन्मस्थल लुम्बिनीको विकासक्रम एवं महत्त्व स्पष्ट हुने आशा गर्न सकिन्छ।

\section{अध्ययन विधि एवं सामग्रीहरू}

वैदिककालमै तत्त्वदर्शन उच्चतामा पुगेको अवस्था सहन नसक्ने आस्तिक विचारहरूले तात्त्रिक विचारधारा विरुद्ध शुरु गरेको प्रतिक्रियालाई परिसमाप्ति गरेर समाजलाई नविन सभ्यताको मार्ग प्रदान गर्ने बौद्ध दर्शनका प्रणेता गौतम बुद्ध विचारक-उपदेशक मात्र नभै नीतिज्ञ तथा विद्वान् पनि थिए। अनेकौं जाति-वर्णको प्रचलनले गर्दा अस्तव्यस्त संरचनायुक्त समाज रहेको आफ्नो युगको आस्तिक तथा नास्तिक दुवै विचारधारा मनन गरि परिचय प्राप्त गर्दे आत्मशुद्धिद्वारा सत्यको खोजी सकेर बोधि ज्ञान प्राप्त गरिसकेपछि बुद्ध बनेका उनले प्राप्त ज्ञानलाई सर्वसाधारणमा वितरण गरिदिनु नै जीवनको ध्येय बनाएको पाइन्छ। सांसारिक दु:ख र जन्म-मरणको चक्रबाट मुक्ति पाउन फेरि जन्मन नपर्ने अवस्थालाई निर्वाणको संज्ञा दिएर अष्टाझ्ग मार्ग अवलम्बन गरि इच्छामुक्तिको स्थितिमा मात्र निर्वाण प्राप्त हुने सार सहितका उनका उपदेशहरूले मानिसहरूको व्यवहारिक तथा नैतिक जीवनमा राम्रो असर परेको छ। अहिंसा, शान्ति, मैत्री, क्षमा र करुणाका सन्देशहरू समेटिएका बौद्ध उपदेशहरू सम्पूर्ण मानव जातिका लागि अनुकरणीय बन्दै आएकाले विश्व शान्तिका जनकको उपाधि प्रदान गरिएका गौतम बुद्धको जन्मस्थल लुम्बिनीलाई विश्वशान्तिको मुहान नामाकरण गरिसकिएको छ। शक्ति विस्तारको होडबाजीयुक्त राजनीतिक स्थितिमा अस्तव्यस्त आर्थिक-सामाजिक संरचनाबाट प्रभावित मानव जगत्लाई नविनताको बाटोमा बढाउने महापुरुषको जन्मस्थलको ऐतिहासिकता, विकासक्रम र दर्शनबारेको समिक्षात्मक विश्लेषणमा केन्द्रित यो लेख विविध स्रोतहरूमा आधारित पुस्तक, लेख, घोषणापत्र, कार्यपत्र, पत्रपत्रिका, मर्मजहरूका धारणा आदिको सहयोगमा तयार पारिएको छ। 
मूलतः प्राथमिक र सहायक स्रोतहरूमा अन्तर्निहित भएर प्रस्तुत लेख तयार पार्ने कममा स्रोत सामग्रीहरूको परीक्षण, पुनर्परीक्षण, सत्यान्वेषण गरेर निस्किएका निष्कर्षहरूलाई विश्वसनीय तवरले प्रयोग-प्रस्तुतीकरणमा ल्याइएको छ। त्यसैगरी छलफल, सम्वाद, सम्बोधन, विज्ञप्ति, अपिल, सन्देश आदिबाट प्राप्त ऐतिहासिक तथ्यहरूलाई पनि महत्त्वपूर्ण स्रोतका रूपमा मनन गरि प्रयोग गरिएको छ। ऐतिहासिक धारा अनुसार बढदा शोधविधि र प्रक्रियागत पद्धति अपनाएर तयार पारिएको प्रस्तुत अध्ययनमा शिकागो विधिमा आधारित पुछ्छेनोट स्थापना गरि अन्तमा सन्दर्भ सामग्रीहरू संयोजन गर्ने काम भएको छ। बुद्ध जन्मस्थल लुम्बिनीको प्राचीनता, विकासक्रम, महत्त्वसँगै शाक्यवंशको उत्पत्तिलाई पुस्तकालय अध्ययनसंगै लुम्बिनी विकास कोषबाट उपलव्ध दस्तावेजहरू, विभिन्न गोष्ठी-सम्मेलनका कार्यपत्र-टिप्पणीपत्रहरू, लुम्बिनी विकासमा संलग्न प्राज्ञ एवं पदाधिकारीहरूका धारणा र इतिहास-सँस्कृतिविद्हुरूको मार्ग निर्देशन आदिका आधारमा समीक्षात्मक विश्लेषण गरेर निष्कर्ष निकालिएको छ।

\section{लुम्बिनीको अवस्थिति- नामाकरण}

जातिय विविधताभित्र साँस्कृतिक विभिन्नता भएर पनि सामाजिक सद्भाव र एकतायुक्त मुलुक मानिने नेपाल विविध धर्म र दर्शनको फूलबारी पनि हो। मानव सभ्यताको विकासक्रममा उदय भएका विभिन्न धर्म एवं दर्शनहरूले नै मानिसलाई आस्था विश्वासको मार्ग प्रदान गरि कर्मयोगी बनाएका दृष्टान्तहरू धार्मिक दर्शनहरूमै पढ्न पाइन्छ। पौराणिक समयदेखि नै हिन्दू धर्मको प्रभाव क्षेत्रका रूपमा परिचित राष्ट्र नेपालको समाजका विविध जनजाति समूहहरूले धर्म संस्कृतिका रूपमा अवलम्बन गर्ने बौद्ध धर्मले पनि हिन्दू धर्मले जस्तै प्रभाव पारेको छ (शाक्य, १९९५ : २९)। विश्वका बौद्धमार्गीहरूले अत्यन्त महत्त्वपूर्ण तीर्थस्थल मान्ने लुम्बिनी अधिकांश हिन्दूहरूको पनि महत्त्वपूर्ण धार्मिक गन्तव्यका रूपमा परिचित छ। विश्वजगत्ले नै अपार श्रद्धासाथ पवित्रभूमि स्वीकार गरेको लुम्बिनी साँस्कृतिक धार्मिक महत्त्वको पवित्र क्षेत्र हो ।

वर्तमानमा गणतन्त्र नेपालको प्रदेश नं. $y$ को लुम्बिनी अज्चल रूपन्देही जिल्लाअन्तर्गतको लुम्बिनी साँस्कृतिक नगरपालिकामा अवस्थित बुद्ध जन्मस्थल लुम्बिनी भैरहवाभन्दा २२ की.मी. पश्चिममा पर्दछ। विश्व जगत्ले पवित्रभूमि स्वकिर गरेको लुम्बिनी प्राचीन शाक्य राज्य कपिलवस्तु र कोलिय राज्य रामग्रामको सिमावर्ती क्षेत्र पनि भनेको भेटिन्छ। तराइको गर्मीमा हुर्कने सालजस्ता वृक्षहरूसँगै विभिन्न फलफूलका रुखहरूले ढाकिएको यो स्थल वैवाहिक समेतका सम्बन्धमा बाँधिएका दुबै राज्यका शासक एवं तिनका परिवार वनविहारका लागि आउने ठाउँ भएकाले सुन्दर बगैंचा अर्थात् उपवनका रूपमा विकसित संरक्षित गरेर लुम्बिनी कनाना, लुम्बिनी बाटिका, लुम्बिनी उपवन, लुम्बिनी किट्टलवन, प्रदिमोक्षवन आदिनामले उल्लेख गरेको पाइन्छ। कपिलवस्तु शाक्य गणराज्यको राजधानी तिलौराकोटभन्दा २Y की.मी. पूर्व तेलार नदी किनारमा घना शाल्मली वृक्षहरूद्वारा ढाकिएको कपिलवस्तु- रामग्रामको संयुक्त स्वामित्वमा रहेको र रंगीविरंगी फूलहरूद्वारा सिंगारिएको यो उपवनको नामाकरणबारे भने एकरूपता पाइंदैन । 
ठूलाठूला सालका वृक्षहरूद्वारा घेरिएकाले सुरक्षित रहेको लुम्बिनीमा विद्यमान सुन्दर फक्रिएका फूलहरूको सुवासले खिचिएका माहुरीहरूको देदिप्यमान भुनभुनाहट र विभिन्न रंगका चराचुरुड्डीहरूको मिठो संगीत गुज्जिरहने भएकाले चित्रलताकुज्जका नामले चिनिने इन्द्रको स्वर्गमा अवस्थित उद्यान सदृश मानिन्थ्यो (रिजाल, १९७९ : १२-१३)। आफनो असिमित सौन्दर्यले मानिसहरूलाई प्रभावित वा आकर्षित पार्ने स्थलका रूपमा उल्लेखित यो ठाउँ प्रारम्भदेखि नै लुम्बिनीका नामले चिनिन्थ्यो भन्ने एकथरीको विचार विपरित गौतम बुद्धको मातामही समेतको नामबाट नामाकरण गरिएको भन्ने विश्वास पनि पाइन्छ। राजकुमार सिद्धार्थकि मातामहीको नाम लुम्बिनी, रानी महामाया देवी (मायादेवी) कि आमाको नाम लुम्बिनी रहेको एकथरीको धारणा विपरित आचार्य अमृतानन्दले राजा अन्जना शाक्यकि रानी लुम्बिनी रहेको मानेका छन् (वर्ल्ड बुद्धिष्ट, नोभेम्वर ३०डिसेम्बर २, १९९६ : १३)। जातक अट्टकथा, सुत्तनिपटा, नलकासुत्त, दिग्धनिकाय, समुक्ता निकाय आदि धेरै बौद्ध साहित्य एवं स्रोतहरूको हवाला दिइएको एक प्रतिवेदनले पनि देवदहका राजाद्वारा आफ्नी रानी लुम्बिनीको चाहना पूरा गर्न अत्यन्त सुन्दर उपवन तयार गरिदिएको लामो कथा उल्लेख गरेको छ (जनरल सेक्रेटरी, २००० : १-२)। त्यसबाहेक रकहिल समेतबाट देवदहका राजा सुप्रबुद्धक रानी, राजा सुप्रबुद्धका मुख्यमन्त्रीकी रानी, एवं राजकुमारी एशोधराकी आमाको नाम लुम्बिनी रहेको तर्क दिंदै त्यसैका आधारमा नामाकरण भएको पनि भनिएको छ। यस स्थलका बारेमा उल्लेख गर्ने विद्वान् लेखक, तीर्थयात्रीहरूद्वारा पनि आ-आफ़ना उच्चारणका आधारमा पृथक पृथक नामले सम्बोधन गरेको भेटिन्छ। जसको पुष्टिका लागि जातक कथामा Lumbini forest, अशोक स्तम्भ अभिलेखमा Lu-Mi-Ni, प्रसिद्ध चिनिया यात्री Fa-Hein को यात्रा बृतान्तमा LunMin, jf Lun-Ming भन्दै भगवान् बुद्धलाई जन्म दिएपछि रानी महामायादेवीसँग सम्बन्धित वस्तुहरू उल्लेख गरेको, अर्को चिनिया यात्री ह्वेन-साइ़द्वारा La-fa-na र अर्का चिनिया यात्रीले Loungni-Ni Lan-Pi-Ni भनेको प्रसझ्गहरूलाई लिन सकिन्छ (वर्ल्ड बुद्धिष्ट..., नोभेम्बर ३०-डिसेम्बर २, १९९६ : १३)। समयक्रममा उजाडिदै गएको लुम्बिनीको इतिहास उल्लेखित चिनिया यात्रीहरूका विवरणबाट पछि गएर लुम्बिनी खोजि कार्यमा सघाउ पुगेको विषयबारे यथास्थानमा चर्चा गरिने छ।

शाक्य एवं कोलियहरूले आमोद प्रमोदका लागि बनाएको लुम्बिनी उनीहरूको पतनपछि, पनि महत्त्वपूर्ण रह्यो । बौद्ध धर्ममा आस्था राख्ने तीर्थयात्रीहरूदेखि भिक्षुहरूसम्मले दर्शनीय पवित्रस्थल मानेर आइरहने, बस्ने गरेकाले वरिपरीका क्षेत्रहरू उजाडिदा पनि जोडिदै आएको लुम्बिनी भारतीय क्षेत्रमा बढदो मुसलमानी प्रभाव, नेपालमा विभाजित हुँदै गएका राज्य रजौटा र राजनैतिक प्रभाव बढाउने होडबाजीले गर्दा ओभेलमा पर्दे गयो। सभ्यताहरू नष्ट हुने ऋममै जड्गलमा परिणत हुँदै गएको अवस्थामा जड्गलमै हराएको लुम्बिनी समयक्रममा खोजीको विषय बन्दे भेटिएर महत्त्वपूर्ण स्थलको पहिचान कायम गरेको तथ्यबारे यसपछिका प्रसझ्गहूमा चर्चा हुने नै छ।

\section{शाक्य वंशको उदय र सिद्धार्थ गौतमको जन्म}

नेपाली भूभागमा विक्रम सम्वत्को थालनीभन्दा निकै पहिला विभिन्न क्षेत्रमा सभ्यताहरू विकसित हुँदै थिए । धरातलीय विषमताले गर्दा सालैभर हिउँले ढाकिने देखि घना जड्गलले भरिएका क्षेत्रहरू सहितको नेपाली 
भूखण्डमा समयको गतिसँगै पूर्ण वेगसाथ बग्ने नदी प्रणाली सम्भव भएकाले पहाडदेखि तराईसम्मका क्षेत्रमा ठूला साना उपत्यका, नदी बेँसी, समथर फाँट र दक्षिणका विशाल मैदानहरू बन्न गएका हुन् । उच्च पहाडि एवं उपत्यका क्षेत्र सँगै एशियाका नदी किनारी क्षेत्रमा विकसित मानव सभ्यता ज्ञान प्राप्तिको चरणमा पुगेपछि, भोलादेखि गंगासम्मको क्षेत्रमा बस्ने गृहस्थीदेखि शासकहरूसम्ममै चलायमान स्थिति र अवस्था देखा पच्यो । फलस्वरूप नेपालको काठमाडौं उपत्यका संगै तराइको मिथिला वा जनकपुर, कौसिकि प्रदेश, कपिलवस्तु, रामग्राम, आदि ठाउँहरूमा उत्कृष्ट समाजहरूको उदय-विकास हुँदै राज्य-गणराज्यहरू स्थापना, शक्ति संचय, विस्तार कार्य बढेको हो ।

नेपालका प्रमुख प्राचीन सभ्यताहरूमध्येकै एक मानिएको शाक्य सभ्यता वर्तमान नेपालको लुम्बिनी अन्चल अन्तर्गत कपिलवस्तु जिल्लाको सदरमुकाम तौलिहवा निकटको तिलौराकोटमा विकसित भएको हो । कपिलवस्तु नामले राज्य तथा राजधानी दुवैलाई चिनिने राजतन्त्रात्मक शाक्य गणराज्यलाई बौद्ध ग्रन्थ तथा विद्वान्हरूले पूर्वमा रोहिणी नदी, पश्चिममा अचिरावती, दक्षिण-पश्चिममा कोशल राज्यको श्रावस्ती, दक्षिण-पूर्वमा मल्ल राज्य र उत्तरमा हिमालयसम्म फैलिएको उल्लेख गरेका छन् (विडारी, २००३: ४६ $)$ ) यो राज्यलाई हिमालयको तल्लो पाखो, भागिरथी नदी (हाल वाणगंगा) छेड र शकवृक्ष (साल) हरूको जड्गल क्षेत्रमा अवस्थित रहेको देखाउने बौद्ध ग्रन्थ दिग्धनिकायको अम्बेस्थ सूत्र संगै सुमंगल विलासिनी, अश्वघोषको महाकाव्य, सौन्दरानन्द, ललितविस्तार तथा जातक कथाहरू आदि ग्रन्थहरूमा कपिलवस्तु राज्य स्थापनाका कथाहरू पढ्न सकिन्छ (रकहिल, १६द४ : ११-१२)। सबैजसोमा उल्लेखित धारणा अनुसार साकेतका राजा इक्ष्वाकु (कसैले ओकाक पनि भनेका छन्) $y$ छोरी र $\gamma$ छोरा जन्माएक रानीको असामयीक निधन पछि, दोस्रो विवाह गर्न बाध्य भए। दोस्रो पत्नी अर्थात रानी बनेकी जयन्तीले केही समयमै जन्माएको पुत्र जयन्तुलाई राजा बनाउने चाहना राखेर दबाव दिन थालेकिले उनको वशमा परेका राजाबाट उल्कामुख, करकण्ड, हथिनिक, सिनीपुत्र नामक छोराहरूसँगै प्रिया, सुप्रिया, अनन्द, विजिता, विजितसेन नामक $y$ छोरी गरि $\rho$ सन्तानलाई दवावपूर्ण रूपले राज्य बाटै निष्कासन गरियो (विडारी, २००३ : प९ं; विडारी, १९९४ : ४४ ; जनरल सेक्रेटरी, २००० : ४)। विना अपराध पाएको निष्कासनलाई स्वीकारेका राजकुमार राजकुमारीहरू साकेतबाट निस्केर हिमालयतर्फ बढ़ने ऋममा भागिरथिका नामले पुकारिने वर्तमान वाणगंगा नदी किनारमा आइपुगे। कपिल ऋषिको आश्रमद्वारा सुसज्जित उक्त ठाउँमा पुगेपछि आश्रय एवं सल्लाह मागेका राजकुमार राजकुमारीलाई बस्ने अनुमती दिएका कपिल ऋषिले उपयुक्त हुने क्षेत्र पनि देखाइदिए ।

कपिल ऋषिको सम्मति पछि शकवृक्षहरूको फँडानी गरी बस्ती बसाल्ने कार्य थालेका राजकुमार र राजकुमारीहरूले समयक्रममा सुन्दर नगर हुँदै शहर-राज्यमा परिणत गरे । त्यसै कममा आफ्नो रगतलाई शुद्धता दिन जरुरी ठानेका उनीहरूले ऋषि कपिलको परामर्शसमेत लिई जेठी राजकुमारी प्रिया बाहेकले दाजु बहिनीमै विवाह गरेर प्रशस्त सन्तान पनि जन्माए (रकहिल, १६६४ : १२)। अविवाहित जेठी राजकुमारी प्रियाले राजमाता सरहभै संरक्षण-व्यवस्थापन थालेपछि कपिल ऋषिकै गोत्र गौतम स्वीकारेका उनीहरूले ऋषिद्वारा निर्धारित ठाउँमा शहर 
बसाउने ऋममा ऋषिले दिएको माटोको प्रयोगले महल खडा गरे । त्यसरी तयार भएको शहरलाई कपिलको माटो वा भूमिका रूपमा लिएका उनीहरूले कपिलवस्तु नामाकरण गरेको धारणा रकहिलले प्रस्तुत गरेका छन् । यसप्रकार ऋषि कपिलको गोत्र स्वीकारेका उनीहरू समयक्रमा कसरी शाक्य भनिए भन्ने बारे खोजीनीति गर्दा पृथक पृथक धारणाहरू पाइन्छन् । त्यसै विषयमा कलम चलाउनेहरूसमेतबाट किटान गर्न नसकेको स्थितिमा थप अध्ययन अनुसन्धान आवश्यक पर्ने जनाउँदै प्राप्त स्रोतहरूका आधारमा समग्रतामा उल्लेख प्रयास गरिएको छ।

शक अर्थात साल वृक्षहरूले ढाकिएको जड्गल फाँडेर बस्ति बसाउँदै सुन्दर समृद्ध राज्य कायम गरेको अवस्थामा प्रभावित स्थानीय समुदायहरूद्वारा शाक्य भनिएको भन्ने धारणा विपरित रक्त शुद्धतापछिको सफलतासँग जोडिएको धारणा पाइन्छ। जसमा रक्त शुद्धताका लागि आपसमै विवाह गरेका राजकुमार र राजकुमारीहरूले छोटो समयमै समृद्ध कपिलवस्तु राज्य बनाएपछि कुशिनगर, वैशाली, कौशाम्वि, श्रावस्तीसम्म जोड्ने काम भयो। यिनीहरूको फैलदो प्रसिद्धि सुन्ने क्रमा एक्काशि आफूले निस्काशित गरेका छोराछोरी सम्किएका साकेत नरेश इक्ष्वाकु (कसैले ओकाक भनेका) ले मन्त्रीहरूसँग सोधे। सबै कुरा पत्ता लगाएका मन्त्रीहरूबाट उत्तरमा हिमालयको तलहट्टिमुनी पवित्र नदी किनारमा अवस्थित शक उपवनभित्र सम्पन्न राज्य खडा गरिबसेको विवरण प्रष्ट पार्ने काम भयो। रित्तो हात धपाइएका सन्तानहरूको उन्नती प्रगतीका समाचारबाट हर्षविभोर भएका राजा इक्ष्वाकुबाट "शाक्य वट भो कुमार, परम शाक्यवट भो कुमार" अर्थात् आहा ! समर्थवान (शाक्य) साँच्चै समर्थवान (शाक्य) रहेको कुमारहरू ! भन्दै खुशी व्यक्त गरेकाले समयक्रममा यिनीहरू शाक्य कहलाइएका हुन् । त्यसबाहेक यिनीहरू साकेतबाट आएका हुनाले सोही स्थलकै नामका आधारमा साकेता हुँदै शाक्य भएको तर्क दिनेहरू पनि भेटिन्छन्। समग्रमा शाक्य भनिनुका पछाडि शकवृक्षको जड़गल फाँडेर राज्य स्थापना गरेको, पिताद्वारा समर्थवान (शाक्य) भनिएको, साकेतबाट आएकाले र सन्त कपिलको आशिर्वादमा राज्य खडा गरेको तर्कहरू पाइन्छ (मिश्र, १९७६ : १; जनरल सेक्रेटरी, २००० : ४-६; रिजाल, १९९६ : २१-२२; विडारी, १९९४ : ४४ ; विडारी, २००३ : ४६ -४९९; सुवेदी, २००४ : ४९-४०; रकहिल, १६६४ : १२-१३)। यसप्रकार निर्वासित राजकुमार राजकुमारीहरूद्वारा घना जड्गलले जेलेको पवित्र नदी किनार क्षेत्रमा कपिल ऋषिको सम्मतीले राज्य खडा गरेपछि, शाक्य क्षेत्रीय वंशी भन्न थालिएको हो। कट्टर हिन्दू सनातनी परम्परामा हुर्किएका उनीहरूले त्यसै अनुरूप राजकाज सन्चालन गर्दा काटमार एवं बलीपूजा समेत गरेको र कपिल ऋषिद्वारा अनुसन्धान अुष्ठान गरिएको साड्ख्यदर्शनको पालनातर्फ पनि लागेर विस्तारित, सबल र समृद्ध राज्य बनाएका हुन्।

कपिलवस्तु राज्य खडा भएको केही समयमै राजमाता प्रिया अकस्मात कुष्ठरोग पिडित भइन् । कुष्ठरोगलाई समाजले संक्रामक रोग ठान्ने, पापको फल मान्ने र छिछि एवं दुरदुर गर्ने प्रवृत्ति भएकाले उनी नगर छाडेर घना जड्गलभित्रको गुफामा बस्न थालिन्। संयोगवश रामा नामले चिनिने वाराणसीका राजा पनि यही रोग लागेकाले राजपाठ छोरालाई सुम्पिएर वनवासका लागि त्यही जड्गलतर्फ आए। यत्रतत्र भट्किंदै हिंड्ने कममा संयोगवश कोलनको रुख (Naucleacordifolia) मुनी बस्न पुगेका रामालाई ऋमश: ठिक हुँदै गएकाले कुष्ठरोग मुक्त 
भए । त्यसपछि खुसी भएर वनमै विचरण गर्ने ऋममा संयोगवस कुष्ठरोगि प्रियालाई भेटेका उनले आफ्नो वृत्तान्त सुनाएर कोलनको रुखमुनी बस्न लगाए। केही समयमै प्रिया पनि कुष्ठरोग मुक्त भएर सुन्दर तन्दुरुस्त भएकिले प्रशन्न भएका दुवै जनाले आपसमा विवाह गरि सन्तान जन्माउने र वनारसका राजाको सहयोगमा कोला वृक्षद्वारा घेरिएको सहर बसाउने काम गरे। समयक्रममा कोलंगरा वा कोलियपुर भएको यो शहर बाघलाई पासोमा पार्ने ब्याग्रपुरा वा व्याग्रपथ हुँदै देवदह राज्यमा परिणत भएपछि राजाहरू कोलिय वंशिका रूपमा

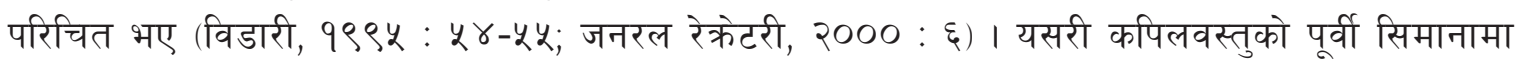
स्थापित देवदह राज्यका शासक कोलियहरूले शाक्यहरूसँग वैवाहिक लगायतका सम्बन्ध कायम गरि आपसी सहयोग सद्भावको स्थिति सिर्जना गरे ।

प्रियाले छाडेर गएपछि प्रमुख बनेका उलकामुखको समयमा सफल, बलियो र समृद्ध बनेको कपिलवस्तुलाई उनका उत्तराधिकारीहरूले कन् शक्तिशाली र समृद्ध बनाए। विशाल शहरहरूसँगै ३०,००० परिवार बनाएका शाक्यहरूले पाँचलाख भन्दा बढी जनसंख्या भएको राज्यमा गणतत्त्रात्मक शासन पद्धती अपनाए (सुवेदी, २००४ : प०)। अर्कातिर ऋमश: सम्पन्न बन्दै आएको छिमेकी देवदह राज्यसँगको वैवाहिक सम्बन्ध पनि समयक्रमसंगै मजबुत हुँदै गयो। कपिलवस्तुमा सिंहहानु र जशोधरा नामक छोराछोरी भएका जयसेन राजा भएका बेला अन्जान र कन्चना नामक छोरा छोरीका पिता ओकाका देवदहका राजा थिए। आ-आफ्ना सन्तानहरूको विवाह गर्ने निश्चय गरेका दुवै राजाबाट निश्चय कार्यान्वयन गरेपछि, कपिलवस्तुका सिंहहानुसँग कन्चनाको र देवदहका अन्जानसँग जशोधराको विवाह भयो (विडारी, २००३ : पू९) । नियतीले पवित्र कार्यका लागि छनौट गरेका उल्लेखित दुइ जोडीहरूमध्ये सिंहहानु र कन्चनाद्वारा शुद्धोधन तथा अन्जान एवं जशोधराबाट महामायादेवी र प्रजापति नामक कन्याहरू जन्मिएपछि, उचित समयमा शुद्धोदनको महामाया र प्रजापतीसँग विवाह भएर सिद्धार्थ गौतमको जन्म हुने पृष्ठभूमि तयार भयो ।

सबैजसो बौद्ध साहित्य-स्रोतहरूले सिद्धार्थ गौतम अर्थात् गौतम बुद्धको जन्मबारे जनश्रुतिको प्रभाव मानेका छन् । सबैजसो लेखक-अनुसन्धानकर्ता एवं कतिपय बौद्ध विद्वान्हरू पनि त्यस्तै स्रोतहरूमा विश्वस्त भएको पाइन्छ। त्यो स्थिति समेतका आधारमा हेर्दा नेपाल तराइको कपिलवस्तु क्षेत्रमा राज्य गर्ने शुद्धोधन नामक राजाले कोलिय राजकुमारी मायादेवीलाई विवाह गरि गतिशील हुँदा पनि लामो समयसम्म सन्तान सुख पाउन सकेका थिएनन् (थेरा, १९६२:७; क्योकाई, २०१६ : २)। तर पनि कत्ति विचलित नभइकन कर्मको दुनियामा बढिरहेका थिए। जनतत्त्रात्मक शासन व्यवस्थाका पक्षपाती शाक्यहरूमा हरेक वर्षको आषाढ महिनामा राजा प्रजा सबै मिलेर एक महोत्सव मनाउने चलन थियो। सामान्यतया एक हप्तासम्म चल्ने उक्त महोत्सवमा सदाभैँ रमाउने मायादेवीलाई एकपटक अत्यन्त आमोद प्रमोद, सान शौकत प्रदर्शन गर्दे फलफूलहरूका साथै सुगन्धित साधनहरूले सम्पन्न भएर मनाउने इच्छा वा चाहना उत्पन्न भयो (आंवेडकर (क), १९५७ :६)। सुरापान समेतका नशावान वस्तुहरूको प्रयोग वर्जित उक्त समारोहको सातौं दिन सबेरै उठेकि मायादेवीले सुगन्धित जलले स्नान गरी चारलाख कार्षापणहरू दान गरेर अन्तमा वस्त्रालङ्कार पहिरि विधिपूर्वक ब्रत पूरा गरेर मिठो 
खाना खाएपछि अत्यन्त सुसज्जित पारिएको शयन कक्षभित्र गइन् । उत्साह र प्रेमसाथ स्वागत गरेका राजा शुद्धोदनसंगको प्रेमिल मिलन पछि राजकीय शैयामा सुतिरहेकी उनी तन्द्रामा पुगदा नपुग्दै एक स्वप्न देखिन् । अकस्मात आएका चातुर्दिक देवताहरूले पलड्ग समेत आफूलाई उठाएर लगि मनोशिलामा पुच्याइ दिएपछि, आइपुगेका देवकन्याहरूले अनोतप्त नामक दहमा लगेर नुहाइदिंदै मनुष्य गन्धरहित बनाएर दिब्यवस्त्रालड्कार, सुगन्धलेपनद्वारा सुशोभित पारि कनक विमानको पूर्व शिरासनयुक्त पलझ्ममा शयन गराए (गर्ज, २००६ : ६; अमृतानन्द, १९९६: २)। त्यसैबेला तुषित देवलोकमा बस्ने श्वेतकेतु वोधिसत्व प्रकट भएर पृथ्वीमा अन्तिम जन्म लिने चाहना राखेको जनाउँदै माताबन्न स्वीकार भए नभएको सोधेकाले खुशी साथ भन्दै मायादेवीले स्वीकृति जनाएपछि सेतो वर्णको हात्तिको रूप धारण गरेर पलङलाई परिक्रमा गरि दाहिने काखिमुनीबाट रानीको पेटभित्र प्रवेश गरे (आंवेडकर, १९५७ : १२; अमृतानन्द, १९९९ : २; सालुड्खे, २०१७ : २६)। बौद्ध साहित्यहरूको अध्ययनका आधारमा तयार एक सामाग्रीले भने पृथ्वीतलको संसारमा आएर ज्ञानको प्रकाश छर्ने निश्चय गरेको वोधिसत्वले धेरै क्षेत्र एवं ठाउँ, जात-वर्ग आदिबारे सोच विचार गरेपछि, मात्र मायादेवीको पुत्र बन्ने निर्णय गरेको उल्लेख गरेको छ, (जनरल सेक्रेटरी, २००० : ७)। त्यस्तो स्वप्नापछि डराएको स्थितिमा उठेकि रानीले सबै कुरा बताएर अर्थ जान्न खोजेपछि, आफ़ना ब्राह्मणाचार्यहरूलाई डाक्न पठाएका राजाले उचित सत्कारपछि, स्वप्नको अर्थ सोधे। पहाडिमूलका ब्राहम्माचार्यहरूबाट आपसी परामर्शपछि महारानीको कोखबाट महापुरुषले जन्म लिन लागेको योग देखिएको जनाएर राजपाठ-गृहस्थमा रमाएमा चक्रवर्ती राजा हुने अनि गृहत्यागि सन्यासी भएमा बुद्ध अर्थात् सर्वज्ञ बन्ने सम्भावना बताइदिए (सालुड्खे, २०१७ : २९; आंवेडकर, १९५७ : १२-१३)। सन्तान प्राप्तिको समाचारयुक्त जवाफबाट आनन्द विभोर भएका राजाले राज्यभरी उत्सव मनाउन हुकुम दिएपछि कपिलवस्तु खुसीमा भुम्न थाल्यो। समयक्रम सँगै आवश्यक स्याहार सुसार पाएकी रानी मायादेवीको गर्भ पनि हुर्कदै र फक्रै गयो ।

राजा शुद्धोदनको व्यवस्थापनमा कुनै कष्ट बिना करिब १० महिना पूरा भएपछि रानी मायादेवीले राजा समक्ष माइतीघर देवदह जाने इच्छा व्यक्त गरिन्। पहिलो बच्चा माइती घरमा जन्माउने परम्परा अनुरूप रानीको इच्छा आएपछि, स्वीकार गरेका राजाबाट सुन्दर पालकीको व्यवस्था गरेर सेवक, सेविका, सैनिक सहित विदा दिए (विडारी, १९९५ : पूy) । उच्च सुरक्षासाथ सेविकासहितको टोली देवदहतर्फ बढेर लुम्बिनी उपवनमा पुग्यो । सबैजसो बौद्ध साहित्यहरूले कपिलवस्तुको महावन, लुम्बिनी वन, सालवन नाम दिएको लुम्बिनीलाई कपिलवस्तुका शाक्य एवं देवदहका कोलियहरूद्वारा सामूहकि रूपमै संरक्षण-व्यवस्थापन गरिएको आमोद प्रमोद स्थल एवं आरामगृहका रूपमा अर्थ्याएका हुन् (विडारी, २००० : २७)। फुलहरू ढकमक्क फक्रिएका, फक्रिने ऋममा रहेका सुन्दर वृक्षहरूद्वारा शुशोभित, फस्टाउने विभिन्न जातका फलफूलहरूले भरिभराउ लुम्बिनी उपवनमा नयाँ पात-पालुवाहरूले भरिपूर्ण बोट, वृक्ष, फूल आदिले शोभायमान रहेको, चराचुरुड्रीहरू चिरविराइरहेको, भमराहरू भुन्भुनाइरहेको र मन्दमन्द सुसाइ रहेको पवनले मनै प्रफुल्ल पार्ने स्थितिमा पुगेपछि, रानीमा एक्काशि केही समय त्यहाँ बसेर क्रिया गर्ने रमाउने चाहना जागेकाले आफनो पालकी उपवनको उद्यानमा पुय्याउने आदेश दिइन् (आंवेडकर (क), १९५७ : १३)। कपिलवस्तु, देवदहका राजपरिवारका सदस्यहरूदेखि यात्रा गर्ने नागरिक 
यात्रीहरूसम्मले विश्राम लिने स्थल भएकाले पुष्करिणी तलाउ, विश्रामगृह सहितको लुम्बिनी बगैंचालाई विभिन्न प्रकारका फूलहरू, फलफूलका रुखहरू, छायाँदार रुखहरू र औषधीय प्रयोजनका लागि रोपिएका रुख विरुवाहरू समेतले सुसज्जित पारिएको थियो (विडारी, २००० : २७-२६)। मनै प्रफुल्ल हुने उक्त उद्यानमा पुगेपछि, प्रसन्न चित्तसाथ पालकीबाट ओर्लिएक रानी मनपरेका सेविकाहरूसँग उद्यानको प्राकृतिक सौन्दर्यमा रमाउन थालिन् ।

वैशाख महिनाको उमशलागदो गर्मीमा तलाउको शितलजल देखेपछि, पुष्करिणी तलाउमा स्नान गरेकी रानीको शरीरमा हल्का कम्पन भयो। त्यसपछि, निस्किएर तलाउ भन्दा पूर्वतर्फ अवस्थित शाल्मलीवृक्ष तल पुगेकी उनले उभिएर मन्दगतीको पवनले हल्लाइरहेका हाँगाहरूमध्ये सबैभन्दा तल आएको हाँगालाई दाहिने हातले समात्न खोजिन् । रुखको हाँगो समात्न खुट्टा उचालेर पञ्जाको सहायताले उचालिन खोज्दा हल्का प्रसववेदना महसुस गरेर मुख खुम्च्याउँदै दाहिने हातले हाँगा समातेर उभिनासाथ परिस्थिति बुक्केका सेकिवाहरूले तुरुत्तै कपडाको घेरा लगाइदिए। केही क्षण मात्र त्यसरी उभिएकी उनले खासै प्रसवपिडा विना नै सर्व लक्षणयुक्त पुत्रलाई जन्म दिईन। सिद्धार्थ जन्मको विवरण ऋममा बालकलाई “जन्मनासाथ महाब्रहम्माले सुवर्णमय जालमा थापेर रानीलाई दिएको, नवजात बालकले उम्किएर भूमि स्पर्श गरि सात पाइला हिंडेको, मै नै लोकको अग्रपुरुष हुँ, यो नै मेरो अन्तिम जन्म हो भनी घोषणा गरेको आदि अनेकौँ कथाहरू सहितका विवरण बौद्ध कथाहरूमा पाइन्छन् (महर्जन, २००४ : ३१; नदिम, २००९ : १६; जनरल सेक्रेटरी, २००० : ६; शाक्य, मे २००४ : ४४; थेरा, १९६२ :७; आंवेडकर (क), १९४७ : ९-१०; आचार्य, १९४४ : २; अमृतानन्द, १९९९ : ३-६)। मानव जगत्कै लागि महत्त्वपूर्ण सिद्ध हुने सिद्धार्थ जन्म ऋममा मायादेवीले कुनवृक्षको हाँगा समातेर प्रसव यात्रा थालेकी थिइन् भन्ने बारे बौद्ध स्रोतहरूका आधारमा अनुसन्धान गरेका एक अध्येताले पाकडी वा काभ्रो, आँप, पिपल, साल र अशोक गरि पाँच किसमका रुखहरू सम्भावित जनाएर लामो विवेचना गरे तापनि किटान भने गरेका छैनन् (विडारी, २००० : १६-२७)। यसप्रकार स्वर्गका राजा इन्द्रको क्रिडास्थलसँग तुलना गर्न सकिने भनिएको लुम्बिनी उद्यानमा इ.पू. ६२३ वैशाख पूर्णिमाका दिन सिद्धार्थको जन्म भएको समाचार पुगेपछि कपिलवस्तु एवं देवदहका प्रतिष्ठित व्यक्तिहरू जती तुरुत्तै जम्मा भएर आनन्दोत्सव गरेको उल्लेख पाइन्छ।

लुम्बिनी कन्ना, लुम्बिनी बाटिका, लुम्बिनी उपवन, लुम्बिनी चित्तलवनका नामले प्राचीन बौद्ध ग्रन्थहरूले इंगीत गरेको र सालको घनाजड्गलभित्र विभिन्न रंगि विरंगी फूलहरूद्वारा शोभित लुम्बिनी बगैंचामा उत्सव मनाइसकेपछि कुमार सहितको टोली सिन्दुर जात्रा गर्दे कपिलवस्तु फर्कियो । नियतीले निर्धारण गरेको तर हृदयमा ठूलो चाहना भएको भूमिका निर्वाह गरेकि रानी मायादेवीले भने त्यो आनन्दको उपभोग धेरै समय गर्न पाइनन्। नियतीको चक्रव्यूहमा परेकी उनले नवजात सन्तान सुखको आनन्द पनि उठाउन नपाई पुत्र जन्माएको सातौं दिन नश्वर शरीर परित्याग गरेर मृत्यूको आगोस स्वीकार्न बाध्य भइन् । गर्भावस्थाको १० महिना पूरा भएपछिको अवस्था र कच्चि उबडखाबड बाटोको पालकी यात्रा ऋममा असहज स्थिति भएर रक्तस्राव भएकाले निधन भएको हुनसक्ने सम्भावनालाई नकार्न सकिंदैन। त्यसपछि लालन पालनको जिम्मेवारी लिएकी सानीआमा प्रजापती गौतमीले आफ्नै नवजात छोरा नन्दलाई धाइआमाहरूको जिम्मा लगाएर नवजात सिद्धार्थलाई मात्र 
आफ़नो स्तनपान गराई मलमुत्रादि सफा गर्ने लगायत सवै काम आफैं गरि उपकारककै भूमिका निर्वाह गरेर मानव कल्याणका कारकको रक्षा गरिन् ।

\section{महाभिनिष्क्रमण - ज्ञान प्राप्ति र महापरिनिर्वाण}

शाक्य कुलको परम्परा अनुसार जन्मेको पाँचौँ दिन नामाकरण संस्कार आयोजना गरेका राजा शुद्धोदनले त्रिवेदमा पारंगत १०६ ब्राह्मणहरूलाई निमन्त्रणा गरेर विधिपूर्वक कर्म पुच्याउँदै सिद्धार्थ (सर्वार्थसिद्ध) नामाकरण गरि भविष्य सोधे। ज्योतिषादि षट्शास्त्रमा पारझ्त पण्डतहरूूद्वारा पनि अनेकौं परीक्षण पछि, बालक राजपाटमा रुची राखेर गृहस्थाश्रममै रहेमा चक्रवर्ती सम्राट बन्ने तर सन्यासी भएमा त्रिलोकाचार्य सर्वज्ञ बुद्ध हुने योग रहेको स्पष्ट पारि सांसारिक नियम र दु:ख देख्न-भोग्न नपर्ने स्थितिमा हुर्काएमा बुद्धत्वतर्फ लाग्नै नपाउने संकेत गरे । ब्राह्मणहरूको आसय बोध गरेका राजाले पनि सिद्धार्थलाई सदा सुखी र प्रशन्न अवस्थामा राख्ने बाहेक रोग-ब्याधि, वृद्धावस्था, असक्तता, सन्यास एवं मृत्यूबारे जान्ने-देख्ने मौका नै नदिइ हुर्काउन सबैजसो कर्मचारी सेवक सेविकालाई आदेश दिई ऋतु अनुसारका बगैंचा सहितका दरबार सँगै मनबहलाउने आमोद प्रमोदका साधनहरूको व्यवस्था गरिदिने कार्यपछि १६ वर्षकै उमेरमा सुन्दरी कन्या यशोधरासँग विवाह पनि गरिदिए (अमृतानन्द, १९९९ : ९-१५; अधिकारी, २००० : ९४; गर्ज, २००६ : ७-१०)। आयोजित स्वयम्बर कार्यक्रमा लक्ष्यवेध परीक्षा पार गरेर श्रेष्ठता स्थापित गरेपछि, विवाहको अवसर पाएका सिद्धार्थ केही समयसम्म दरबारको रसरझ्ग, आमोद प्रमोद र यशोधरासँगको प्रेममा भुले। छोरा त्यसरी भुलेको देखेपछि पारिवारिक बनेका ठानेर प्रशन्न भएका सुद्धोदनको चाहना अनुसार केही वर्षपछि, नाती राहुलको जन्म पनि भयो। नदी किनारस्थित वाटिकामा रहेका सिद्धार्थलाई छोरा जन्मिएको समाचार पुच्याइएपछि केही क्षण सोचेर ल अब एउटा नयाँ र बलियो बन्धन तयार भयो जसलाई तोड्नै पर्दछ भन्ने प्रीतक्रिया व्यक्त गरेको उल्लेख पाइन्छ (आचार्य, १९४० : ३)। उक्त कुराको जानकारी पाएपछि कस्किएका राजा सुद्धोदनले कामभोगको बन्धनमै भुलाउने निश्चय अनुरूप सुन्दरीहरूद्वारा भरिएको अन्तपुर निर्माण गरि उदायि नामक धाइलाई प्रमुख बनाएर कुमारलाई आकर्षित पारि रसरंगमा बाँधिराख्नु नै उनीहरूको काम कर्तव्य रहेको स्पष्ट गरिदिए (आंवेडकर (क), १९५७: १४)। राजचाहना भित्रको जिम्मेवारी बुक्केका सुन्दरीहरू सारा शक्ति लगाएर वरिपरि भुम्मिएता पनि ऋमशः टाढा जान वा तर्किन थालेका सिद्धार्थमा वाहिरको संसारप्रतिको उत्सुकता बढेकाले अन्तपुर एवं ऋतुवर्णि महलबाट बाहिर निस्केर भोगविलासका साधनलाई नै वेवास्ता गर्ने स्थिति विकास भयो।

आमोद प्रमोदको अवसरसँगै घोडचढी, शस्त्र सज्चालन, राज्यशास्त्र आदि विषयमा राजोचित शिक्षा प्राप्त गरेका सिद्धार्थको चित्तवृत्तिमा सदैव वैराग्य रहेको पाइन्छ। सानैदेखि सांसारिक विषयहरूप्रति वैराग्य विखत रहेका उनले जीवात्माको जीवन रक्षाका लागि आफन्तहरूको स्नेह-चाहना समेतको वेवास्ता गरेर विरोधमै उत्रेका कुरा र विषयवस्तुहरू जातक कथाहरूमा प्रशस्तै भेटिन्छन् । त्यसैक्रममा एकदिन सारथी छन्नद्वारा सिंगारिएको चारघोडे रथमा चढेर उद्यान भ्रमणमा निस्किएका उनले कपाल सेताम्मै फुलेको, दाँत भरीसकेकाले भित्रै धसिएर चाउरी परेका गालायुक्त कुप्रो र लठ्ठि टेकेर काप्दै हिंडिरहेको वृद्धलाई देखेपछि, जिज्ञासा राख्दा सारथीबाट मानिस 
बुढो भएपछि, त्यस्तो हुने जानकारी पाए। त्यसबाट आश्चर्यचकित भएर दरबार फर्किएपछि, विरक्त जस्तै भएर टोलाउन थालेका सिद्धार्थले त्यसपछिका दिनहरूमा रोगी, मुर्दा, सन्यासी आदि पनि देखेर सवैकुरा बुकेपछि अन्तरात्मादेखि नै विरक्ति वा वैराग्य अनुभव गरे। वैराग्यले छोप्न थालेपछि, उत्सुकता शान्त गर्ने ऋममा घर परिवार, जहान, बच्चा, आदि केही नभएकाले खासै मोह बन्धनमा नबाँधिइकन सम्पूर्ण प्राणीहरूमाथि नै समान मैत्री भाव राखेर दु:खको समुन्द्र नै संसार हो भन्ने बोध गरि सन्यासी वा भिक्षु बनेको थाहा पाएपछि, त्यसैलाई उपयुक्त मार्ग ठानेर राज्य एवं सुखभोग छाडि भिक्षु बन्ने संकल्प गरे ।

संकल्प गरेपछि पनि केही दिन पूर्ववत् क्रियाकलापमै लागेर विताएका उनले २९ वर्षको उमेरमा वैशाख पूर्णिमाकै दिन माया मोहमा भुलेर बस्नु अयोग्य र मुर्खता हो भन्ने ठहर गरे। गृह त्याग गरेर जन्म मरणको दु:खबाट छुटकारा पाई निर्वाण पद अवबोध गरेर जगत्को उद्धार गर्ने निर्णय गरेका उनले सारथी छन्नलाई बोलाएर एउटा घोडा ठिक पार्न लगाए। आज्ञा शिरोपर गर्दे अश्वशालाबाट उनको प्रिय कन्थक घोडा ल्याएको सारथीको संकेत पाएपछि २९ वर्षको उमेरमा यौवना सुन्दरी पत्नीको प्रेममय आलिड्गन, नवजात छोराको आनन्दमय अवलोकन- बाललिला, राजकीय वैभव, विशाल साम्राज्य उपभोगको अवसर, मोजमज्जापूर्ण विलाशी जीवन आदि सबै त्यागेर कसैले सुइकोसम्म नपाउने गरि मूल ढोकाबाट सुटुक्क निस्किएर ज्ञान प्राप्तिको मार्गमा बढेको घटनालाई "महाभिनिष्कमण" भानिएको छ (उपाध्याय, १९४६ : ४; आंवेडकर(क), १९५६ : २३-२ (https:..ia801600..: 90-92), महाथेरा, १९९६ : y-๘; अमृतानन्द, १९९९ : १४-२४)। वैशाख पूर्णिमा भएकाले टहटह लागेको पूर्णचन्दमाको प्रकाशमा वेगसाथ रातभर घोडा दौडाएर भार्गवाश्रम नामक तपोवनमा पुगेका सिद्धार्थले अत्यन्त द्रवित भएका छन्नकलाई आफ़नो मोक्षखोजी अभियान बताएर राजकीय वस्त्र एवं आभूषणहरू खोलेर जिम्मा लगाइ घोडा कन्थक सहित कपिलवस्तु फिर्ता पठाई दिए। बचन टार्न नसकि गहभरि आँशु पारेर कन्थकको लगाम समाती हिँडेका छन्न केही पर पुगेपछि, विछोडको पीडा सहन गर्न नसकेको कन्थकले प्राण त्यागेर स्वामीभक्ति प्रदर्शन गरेको उल्लेख पाइन्छ।

महाभिनिष्क्रमण पहि भार्गवाश्रममा केही दिन विताएका सिद्धार्थ मगधअन्तर्गतको राजगृह पुगे । ठूलाठूला घाँटीहरूका बीचमा पहाडहरूद्वारा घेरिएको राजगृहका पहाडी गुफाहरूमा अनेकौं साधु सन्यासीहरू बस्दथे। ध्यान र अध्ययनबाट प्रसिद्ध भएका यस्ता साधु सन्यासीहरूले संसार चिनेको ठानेका सिद्धार्थले सुरुमा केही दिन आलारसँग र त्यसपछि, उद्रक सन्यासीसँग बसेर हिन्दू दर्शनशास्त्रको ज्ञान गरे तापनि सन्तुष्ट हुन सकेनन् (आचार्य, १९४० : y) । त्यसपछिका केही वर्षहरू उपयुक्त गुरु खोज्दै विभिन्न ठाउँका जड्गलहरूमा विचरण गरेका उनले कन्दमुल देखि आफैंले रोपेका फलाएका अन्नमा मात्र निर्भर हुनेहरू, पहाडका भिरपाखा कन्दराहरूदेखि नदीको धारा, सूर्यको खुला ताप वा प्रकाश, तथा प्रज्वलीत अग्नी निकट बसेर तपश्या गर्ने कैयौं साधुहरू भेटे । मृत्यु पश्चात् सुख प्राप्तिको लक्ष्य अनुरूप स्नान, सन्ध्या, होम, तप गर्ने तपश्वीहरू र शरीरलाई कष्ट दिएर हठयोगद्वारा मोक्षको इच्छा राख्ने विद्वान् वेदान्तवादी, सांख्य मतवादी आदिलाई भेटेर सल्लाह लिने, उनीहरूका धर्म तत्त्वहरूबारे मनन एवं वादविवाद सम्मका कार्य गरे (https://ia801600.. १४-१५)। कन्दमूलदेखि 
गाउँहरूबाट मागेको भिक्षाद्वारा जीवन निर्वाह गर्दे बढेका उनले अत्यन्त सावधानीपूर्वक सूक्ष्मदृष्टि दिएर सबैजसो धर्म-दर्शनको ज्ञान लिई चिन्तन गर्न थाले। त्यसैक्रममा आराडकलाम नामक गुरुलाई भेटेपछि आशय बुक्केका गुरुले सांख्य सिद्धान्त अनुकुल आध्यात्मिक मार्गको शिक्षा दिए (उपाध्याय, १९४६ : $y$; आंवेडकर(क), १९५५ : २५-३७)। अन्य विभिन्न ठाउँहूूमा पनि पुगेर कठिन विद्या अध्ययन-अभ्यास गर्दे बढेका उनले आफ्नो शरीर नै सुकेर हाडछाला मात्र बाँकी रहने स्थितिमा पुग्ने सम्मको कठोर तपस्या गरे ।

भोकै बसेर शरीरलाई अत्यन्त कष्ट दिंदै तपश्या गर्दा बेहोस भएर लडेका सिद्धार्थलाई देखेपछि, शुद्रजातको गोठालालाई दया लागेकाले आफ्नो बाखीलाई उनी नजिक पुच्याएर सिधै थुनबाटै मुखमा पारेर केही दुध खुवाईदियो। त्यसबाट केही तागत पाएपछि थपदुध मागेका सिद्धार्थलाई आफ्नो जाति बताएको गोठालाले छोएको खान नहुने जानकारी दियो। जन्मका आधारमा कुनै जाति नहुने तर्क दिएर सम्काउँन खोजेका सिद्धार्थले सदाचारी उच्च र दुराचारी नीच हुने धारणा स्पष्ट गरे । त्यसरी मृत्युको आगोसमै पुग्ने स्थिति आउँदासम्म भोकै रहेर तपश्या गर्दा पनि सफलता नपाएपछि सुजाता नामक शुद्र कन्याले दिएको "पायस" ग्रहण गरी बोधगयास्थित उरुबेला नामक स्थानमा एक पिपलको वृक्षमुनि बसेर ध्यान गर्न थाले। ऋमश: एकाग्रता बढ्दै गएको अवस्थामा वैशाख पूर्णिमाको साँक पूर्ण चन्द्र प्रकाश फैलिएपछि ऋमश: ज्ञानका ढोका खुल्दै गएर पूर्वानुस्मृति ज्ञानदेखि पुनर्वारजन्म सम्मको ज्ञान प्राप्ति अर्थात् आर्यसत्यहरूको साक्षात्कार भएकाले बुद्ध कहलाय (उपाध्याय, १९४६ : ४; कोयोकि, २०१६ : ६-६; आंवेडकर(क), १९५७: ३५-४२; थेरा, १९५२ : १४-१९; महाथेरा, १९९६ : २३-२७; आचार्य, १९५४ : ४-६)। ३४ वर्षको उमेरमा यसप्रकार ज्ञान प्राप्त गरेपछि, केही समय त्यहीं बसेर सम्पूर्ण सिद्धिहरू पुन:याद गरेपछि सारनाथ पुगेका बुद्धले प्राप्त ज्ञानका आधारमा प्रथम उपदेश वा प्रवचन दिए (नदिम, २००९ : १९ं। आजसम्म पनि अत्यन्त सुरक्षित साथ सड्ग्रह गरिएको उक्त उपदेशको पाठमा बुद्ध धर्मको सार - संक्षेप रहेको विश्वास गरिन्छ। यसप्रकार सम्पन्न ज्ञान प्राप्ति पछिको पहिलो उपदेश कार्यलाई धर्म-चक्र प्रवर्तन भनिएको छ।

धर्मचक्र प्रवर्तन पछिको बाँकी जीवन आफ्नो ज्ञान प्रचारमा विताएका बुद्धले विभिन्न ठाउँहरूको भ्रमण गरिरहे । जन्मिएको नगरको गणराज्यकै आदर्श अनुरूप बढेर पञ्चवर्गीय भिक्षुहरूदेखि मगध नरेश विम्विसार, कोशल नरेश प्रशेनजीत, कौशाम्वि नरेश उदयन, अवन्ती नरेश प्रद्योत, सहित शक्तिशाली राजाहरू, भारदारहरू अनेकौं व्यापारी, धनवान, वैश्यहरू, वैशालीकि नगरवधु आम्रपाली, भद्र वर्गीयहरू, उपतिस्स र कोलित परिब्राजकहरू, यशकुमार सहितका प्रसिद्ध व्यक्तिहरू अनुयायी भएर प्रबज्या पाए । त्यसपछि कपिलवस्तु गएर छोरा, पत्नीलगायतलाई अनुयायी बनाएका उनले बनारस, राजगृह, गया, नालन्दा, पाटलीपुत्र, मथुरा आदि ठाउँहरूमा पुगेर उपदेशप्रचार गर्ने, विहारहरू बनाउन लगाउने, कल्पवास गर्ने कार्यद्वारा धर्म उपदेश-प्रचार गरे । भिक्षुहरूका लागि संघ स्थापना गरेका उनले विनयको उपदेश दिएर उपाशक-उपाशिका तयार गरि संसारभर शान्ति-धर्म प्रचारका लागि पठाउने कार्य निरन्तर गरिरहे। विनयपिटक सड्ग्रहमा पाइने उपदेशद्वारा शान्ति सन्देश फैलाउने ऋममा पण्डितहरूले प्रयोग गर्ने संस्कृत धर्म व्याख्या ऋममा पनि कथा कहानी तथा रोचक दृष्टान्तहरू प्रदान गर्ने 
परम्परा अपनाएका थिए। जसले गर्दा यिनको जीवनकालमै फैलिएको बौद्ध दर्शनले धर्मकै रूप लिएर उपदेशमा प्रयुक्त कथाहरू जातक कथाका रूपमा सुरक्षित रहिरहे (आंवेडकर(क), १९५७ : पून-६द; नदिम, २००९ : १७, २३-४०; उपाध्याय, १९४६ : ४ू-६; आचार्य, १९४० : ६-२१; आचार्य, १९५४ : ४-६; अमृतानन्द, १९९९ : ३७-१९०)। अनवरत रूपले ज्ञान बाँड्दै, भिक्षुहरू बनाउँदै जगतकल्याण एवं धर्म प्रचारमा पठाउँदै हिंड्ने र कहिल्यै एकै ठाउँमा लामो समय नबस्ने गरेर धर्मोपदेश दिंदै बढ्दा ऽ० वर्षको वृद्ध उमेर पुगेकै दिन वैशाख पूर्णिमामा मल्ल गणतन्त्रको राजधानी कुशिनगरमा बुद्धले नश्वर शरीर परित्याग गरे। यसप्रकार जन्म, गृहत्याग, ज्ञान प्राप्ति र महापरिनिर्वाण वैशाख पूर्णिमाकै तिथिमा भएकाले बौद्ध धर्म-दर्शनको इतिहासमा यो तिथि वा दिन अत्यन्त महत्त्वपूर्ण मानिन्छ ।

\section{बुद्धबचन वा बौद्ध दर्शनको सारतत्त्व}

पिटकहरूको अध्ययन-विश्लेषण गर्दा बौद्धकालिन समाजमा अनेकौं जाति तथा वर्णहरूको विषमताले गर्दा जातीय विभाजनको स्थिति युक्त समाजमा दयावानदेखि लुटेरासम्म, सम्पन्नताले भरिपूर्णदेखि भोकको ज्वाला शान्त पार्न हात थापेर हिंड्नेहरूसम्म, चोरीलाई नै पेशा बनाएर धनाढ्यहरूको घरमा हातसाफ गर्नुलाई अधिकार सम्भनेहरूदेखि काम बासनामै डुबेर भोग विलासको बाटो अवलम्बन गर्ने र सुन्दरी कन्या- नारीलाई अधिकार ठान्दै वेश्यावृत्तिलाई प्रोत्साहन गर्ने व्यभिचारीहरूसम्मको क्रियाशिलताका अनेकौँ उदाहरणहरू पाइन्छन् (उपाध्याय, १९४६ : १९-२०)। भारतीय उपमाहाद्विपीयक्षेत्रमा जीवन-मृत्यूको चक्रबाट मुक्तिको चाहना राखेर जनावरहरूको बली दिने वैदिक धर्मको प्रचुरता रहेको स्थिति वा अवस्थामा सालका रुखहरूद्वारा घेरिएको लुम्बिनी उपवनमा जन्मिएका बुद्ध (सिद्धार्थ) एशियाकै महत्त्वपूर्ण इश्वर (भगवान) बनेका थिए (सांकृत्यायन, १९४६ : १९-२४)। राजशि सुख सयलबाट पनि शान्ति सन्तोष नपाएपछि घरबार, श्रीसम्पत्ति, राजपाठ सबै त्यागि ज्ञानको खोजीमा हिंडेर बोधगयामा बुद्धत्व प्राप्त गरेपछि आर्यावर्तभरि घुमेर अहमवादमा डुबेका, गलत सोचाइमा परेका, रसरंगमा भुलेर मानवियता बिर्सी व्यभिचारी बनेका अज्ञानताले पछि, परेकाहरूलाई ज्ञान बाँडेर महापरिनिर्वाण प्राप्त गरेका बुद्ध बचनहरू नै समयक्रममा बौद्ध दर्शनमा परिणत भएका हुन् (पाण्डे, १९९४ : ३७)। जात र वर्गको नीति नै उच्च नैतिकता, ज्ञान र मोक्ष प्राप्तिको सवैभन्दा ठूलो बाधा हो भन्ने घोषणा नै गरेका बुद्धलाई जातियताको सिद्धान्त अस्वीकार गरि सकल ब्रह्माण्डका सबै मानिसहरू दाजुभाइ हुन् भन्ने पहिलो दार्शनिक मानिएको छ। 'अति'को चरम मार्गलाई बाधक ठान्ने बुद्धले समाजलाई व्यवस्थित गर्न अति (तिब्र) पन्थ छाड्नु पर्ने कुरामा जोड दिएका छन् ।

प्रारम्भमा ६० भिक्षुहरू तयार गरेर बौद्ध दर्शन वा ज्ञान विस्तारका लागि फरक फरक क्षेत्र वा दिशाहरूमा पठाएका बुद्ध स्वयं भने उरुबेला तर्फ लागे। अप्ठयारो स्वभावयुक्त उरुबेल र काश्यप नामक दुइभाइहरूलाई उपदेशद्वारा दीक्षित गरेपछि कैयौंलाई दीक्षित बनाउँदै हिँडेका उनले अहिंसा र निर्वाणलाई नै स्वर्ग र मुक्ति प्राप्तिका आधार जनाएर ज्ञान एवं योगतर्फ बढ़न सुकाएका छन् (आचार्य, १९乡४ : ६)। मानिसहरूलाई आत्मा-परमात्माको मायाजाल, परम्परा, रितिरिवाज र धार्मिक संस्कारहरू एवं ब्राह्मण कर्मवाद बाट मुक्त नगर्दासम्म मोक्षको बाटो 
देखाउन नसकिने कुरा बुक्रेका बुद्धले ज्ञान प्राप्ति पछिको चरणमा निकै सोच विचार गरेपछि, अनित्य, अनात्मा र दु:खलाई आधार बनाएर बौद्ध धर्मको सिद्धान्त तयार गरेको पाइन्छ (आंवेडकर(क), १९५५७ : पू७) । दु:ख, दु:खको कारण, दु:ख निरोधको सम्भावना र दु:ख निरोधमार्ग जस्ता चार आर्य सत्य अनि प्राणि हिंसा, चोरी, व्यभिचार, कुठबोल्ने र सुरापान-नशापानबाट टाढा रहने पञ्चशिल बुकेर ग्रहण गरेपछि तृष्णा, लालसा, मोह आदि दु:खका कारण हटाई निर्वाण प्राप्त गर्न सम्यक दृष्टि, सम्यक संकल्प, सम्यक बचन, सम्यक कर्म, सम्यक जीविका, सम्यक प्रयत्न, सम्यक स्मृति र सम्यक समाधि जस्ता आर्य अष्टाड़्मार्ग अपनाउनमा जोड दिएका छन् (महास्थविर, २००२ : ४-६; सांकृत्यायन, १९४६ : २३-२७; क्षेत्री र खतिवडा, १९९७ : १३३-१३४; आंवेडकर(क), १९५७ : १०७-११५)। आफ्ना अनुयायीहरूलाई कष्ट-पीडा, कष्ट-पीडाका कारणहरू, दु:ख-पीडाको संहार र दु:ख कष्टलाई संहारको दिशातिर लैजान सक्ने उपायसँग सम्बन्धित महासत्यहरू सिकाएका बुद्धले इन्द्रिय सुखको अभ्यास वा स्व:यातनाको अभ्यासमा कष्ट वा पीडाबाट मुक्त हुने बाटो नरहेको जनाएर त्यसका लागि दुबै बीचको मध्यम मार्ग सही ठहय्याएका छन्।

मध्य मार्गमा सही विचार, सही आकांक्षा, सही बोली, सही व्यवहार, सही जीविका, सही प्रयत्न, सही मन सोचाइ, सही ध्याउन्नाजस्ता आठ मोडहरू जरुरी ठान्ने बुद्धले यसैद्वारा आँखा उघारीने, ज्ञान प्राप्त हुने, महापरिज्ञान हासिल हुने र निर्वाण प्राप्तिमा पुय्याउने ठहर गरेका छन्। रहर वा उत्कण्ठा र त्यसजन्य लोभ लालचको सवै प्रकारका अस्तित्त्वको चाहनालाई चकनाचुर पारी सम्पूर्ण दु:ख कष्टबाट मुक्ति प्राप्त गर्नुलाई निर्वाण प्राप्तिको आधार मान्ने उनले. "निर्वाण" त्यो भन्दा पनि अरु बढ़ी हो भनेका छन्। निर्वाण प्राप्तिलाई उत्तम अवस्था मानि त्यसबाट स्वर्गीय सुख शान्तिको प्राप्ति हुने जनाएर सवै प्रकारका सुख र चाहनाहरूबाट उन्मुक्त व्यक्तिले मात्र त्यस्तो शान्ति अनुभव गर्न सक्ने किटान नै गरेका छन् (नदिम, २००९ : १९)। ज्ञानको खोजीमा निस्केपछि, उत्तरी भारतका विभिन्न ठाउँहरूको भ्रमण, अध्ययन, सोध-खोजको ऋममा हिन्दू धर्मका सिद्धान्त बोध गरेपछि, भ्रममुक्त भएर हिन्दू जातिय व्यवस्था घातक ठहय्याई हिन्दूवादी साधु सन्यासी पनि निरर्थक भएको महसुस गरिसकेको हुँदा नै नौलो दर्शन ल्याउन सकेका हुन्। ज्ञानप्राप्तिपछि, सत्यार्थ मार्गमा बढेका उनले आफ्ना अनुयायीहरू बढाउने, साथै लिएर घुम्ने, नयाँ नयाँ अनुयायीहरू भेला गर्ने, आफ्नो दर्शन-सिद्धान्त बारे प्रवचन दिने कार्य गर्दे गड्गानदी उपत्यका भ्रमण गरे। त्यस कममा जाती प्रथालाई अनर्थक मूर्खताको संज्ञा दिएर उपदेश दिने, जातजातिविहीन समुदायहरू स्थापना गर्ने, संघ परम्पराका नीति नियम अनुरूप त्यस्ता समुदाय संचालन गर्न लगाउने, जातिहीन समाज, समुदाय, मठ, गुम्बा, विहार स्थापना गर्दे बढ्ने काम गरे ।

बुद्ध बचनहरूको विश्लेषण गर्दा- विवेकाश्रित तर्कलाई प्राधान्यता दिएर कारणवादका आधारमा सृष्टिको विश्लेषण गरेको भेटिन्छ। वैदिक समाजमा प्रमुख आधारको स्थान दिइएको दैवी हस्तक्षेपलाई कुनै स्थान नदिइएको बुद्धवाणिहरूले इश्वरलाई सृष्टिकर्ताको मान्यता पनि दिएका छैनन् । सृष्टिकर्ता मान्दा दु:ख उत्पन्न कर्ता पनि इश्वरलाई नै मान्नु पर्ने भएकाले त्यस्तो गरिएको हुन सक्दछ। त्यसैले अनिश्वरवादी दर्शनको छाव बनाएको बौद्ध दर्शनले आत्माको अवधारणालाई परिकल्पना भन्दै आत्मा चिरस्थायि भएको मान्न पनि तयार 
छैन । व्यर्थमा विलाप नगर, तर कुनै पनि कुरा स्थायि छैन भन्ने यथार्थता बुकि यसबाट मानव जीवनको शुन्यताको बारेमा सिक्ने प्रयत्न गर, परिवर्तनीय कुरा अपरिवर्तनीय हुन सक्ने दुस्कामना नगर भनेका उनले सांसारिक तृष्णाको राक्षसले मनलाई भ्रममा पार्न सदैव अवसर खोजी राख्ने जनाएका छन् (क्योकाइ, २०१६ : १३)। कर्मफल र पुनर्जन्ममा भने विश्वास गरेको यो दर्शनले पानीमा उत्पन्न भएको लहरलाई उदाहरणका रूपमा प्रस्तुत गरेको छ। यो जन्मको कर्मफलका आधारमा अर्को जन्ममा प्रवेश गर्ने यथार्थ बुकाउन पानीमा उत्पन्न भएको एउटा लहर जसरी दोस्रो लहरलाई जन्म दिएर समाप्त हुन्छ, त्यसरी नै कर्मफल चेतनाका रूपमा पुनर्जन्मको कारण बन्ने धारणा व्यख्या गरिएको छ। मृत्यूलाई नवीन जीवन आरम्भको कारण मात्र मान्दै त्यसबाट जीवन-मरणको चक्र समाप्त नहुने जनाएर जन्म-मरणको चक्रबाट मुक्ति अर्थात् निर्वाण प्राप्तिको एक मात्र बाटो आष्टांगिक मार्गको अनुशिलनबाट मात्र सम्भव रहेको किटान नै गरेको छ (सांकृत्यायन, १९४६ : ३१-५२; https: //hindi.speaking tree.in)। तिमी छौ त संसार छ, जन्म-मृत्यू, सुख-दु:ख आदि सबै बन्धनहरू हुन्, तिमी मेटियौ भने अरु सबै कुरा मेटिने छ भन्ने बुद्ध सन्देश क्षणभंगुरवादमा आधारित छ। जसले विशिष्ट परिस्थिति वा कारणले गर्दा नै प्रत्येक वस्तु पैदा हुने धारणा अनुरूप प्रत्येक वस्तु अस्थायि वा क्षणभंगुर भएको प्रष्ट पारेर अनात्मवादलाई पुष्टि गर्ने “प्रतित्यसमुत्पाद” सिद्धान्त अनुसार सृष्टि एवं विनाशको कार्य स्वतः र अन्योन्याश्रित छ भन्दछ। त्यसैले बुद्धले इश्वरको सत्तालाई स्वीकार-अस्वीकार केही नगरेका हुन्।

बुद्धवाणिहरूलाई निर्वाण प्राप्तिका लागि गरिने समानार्थक उच्चस्तरीय अभ्यास पनि मानिएको छ। हाल प्रचलित बौद्ध दर्शनलाई विश्लेषणात्मक दृष्टिले हेर्दा त्यसमा बुद्धका सम्पूर्ण उपदेशहरूको प्रयोग नगरी केवल माया मोहको बन्धनबाट मुक्तिको उपायका रूपमा ग्रहण गर्न मिल्ने वा सकिने खालकाहरूमा जोड दिइएको भेटिन्छ (लि, २००६ : ११)। धर्मदेशना अर्थात् उपदेश ऋममा गरेका जीवनचर्या, व्यापार, उन्नती आदि बारेमा गरेका चर्चा र उपदेशहरूलाई भने नजरअन्दाज गरिएको छ। सामाजिक विकृति र विसंगतीयुक्त समाजबारे राम्रोसँग बुक्षेकाले जनजीवनको आधार मानिएको हिन्दु दर्शनका पक्षधरहरूमा व्याप्त धार्मिक सोच, सिद्धान्त र प्रचलनको भित्रैसम्मका विषयवस्तु बुक्केर दिएका उपदेश, बुद्धवाणि अर्थात् धर्मदेशनाले मानिसहरूलाई पुनर्विचार गर्न बाध्य पारेकाले नै बुद्ध आर्यावर्तभरिकै सवैभन्दा ठूला विज्ञ र दार्शनिक बनेका हुन् (पाण्डे, १९९५ : ३७)। बुद्धको धर्मदेशना- दर्शन सुरु भएपछि समाजमा प्रभुत्व जमाइरहेका ब्राह्मणहरू असन्तुष्ट भएर कगडा गर्न आएआइरहे तर बुद्धले तिनलाई तिरस्कार हिंसा गर्दे गरेनन (लामोटे, १९५४ : ४४)। समाजका आवश्यकता र चाहना बुक्षेर दिएका उपदेशहरूलाई आर्यावर्त क्षेत्रले नै स्वीकार गर्नु वा प्रभुत्ववानहरूले विरोध गर्दा पनि बौद्ध दर्शन फैलिनुको मूल कारण उनी सक्षम गुरु भएर नै हो भन्ने धेरैको धारणा छ। मानिसहरूको नैतिकता, समानार्थता, आध्यात्मिकता बोध गर्न सक्ने क्षमता भएकाले नै उनले आफ्ना आर्यअष्टाझ मार्गलाई सबैले बुक्न नसक्ने रहेको स्वीकार गरि माया गर, हिंसा नगर, हेला नगर, निर्वाणका लागि दान शिलद्वारा बोधि ज्ञान प्राप्त गर, राम्रो बोल आदि सामान्य कुरा-व्यवहारहरूलाई दैनिक जीवनमा प्रयोग गर्न लगाएका प्रसझ़लाई लिन सकिन्छ। 
मान्छेको क्षमता अनुसारको ज्ञान मात्र दिनु पर्दछ, भन्ने धारणाका पक्षपाती बुद्धले सबै प्रचलित-पुराना धर्म छाडेर मात्र बुद्ध धर्म दर्शन स्वीकार गर कहिल्यै भनेनन् । पुरानो-प्रचलित हिन्दू धर्म-दर्शनबाटै प्रभावित रहि त्यसैको नीति सिद्धान्त प्रयोग गर्दे पनि बौद्ध धर्म मान्न पाइन्छ भन्ने धारणा राखेका बुद्धले आफनो धर्म-दर्शन मात्र ध्रुवसत्य हो भन्ने कहिल्यै नमानी जादु, तन्त्र, टुनामुना, शक्ति छ भनेर भन्ने कहिल्यै भिक्षु होइनन् हुँदैनन् भनेर स्पष्ट गर्दे ज्ञानकै भरमा मानिसहरू आकर्षित हुने प्रस्ट्याएका छन् (लामोटे, १९५४ : ४५-४६) । खासै तथ्य नबुक्केका साधारण मानिसलाई पनि अरुको आदर सत्कार, माया स्नेह गर्दा, हिंशा नगर्दा, बच्चालाई माया गर्दा, जनावरहरूको रक्षा गर्दाको फाइदा हुन्छ भनेर बुकाउँदै लगेपछि चेतनाको तह बढ़दै जाने र ज्ञान प्राप्तिको उत्सुकता जागेर आउने भएकाले कमश: सिक्दै जान्छ र ज्ञान प्राप्त गरेर दीक्षित हुन्छ भन्ने बुद्ध दर्शन साधारणबाट जटिलतर्फ भन्ने सिद्धान्त अनुरूपकै थियो भन्न सकिन्छ (ली, २००६ : ११-१२)। एकैचोटी ठूलो कुरा, धेरै कुरा सिकाउन खोज्दा असफलता हातलाग्ने स्पष्ट महसुस गरेका उनले मानिसलाई एकैचोटी ठूलो ज्ञान दिंदा भुक्किने वा भ्रमित हुने भएकाले सुरुमा स-साना कुराहरू सिकाएपछि राम्रोसँग बुक्दछ्क्- थप जान्न खोज्दछ् तव मात्र कमवद्ध ज्ञान दिनु पर्दछ भन्ने धारणा व्यक्त गरेका छन्। यसप्रकार बुद्धद्वारा साधारणबाट जटिलतिर हुनेगरि, ऋमबद्ध ज्ञान पाउने गरी फाइदाका उपायबारे सोचेर बुकाएर ज्ञान दिने धारणा व्यक्त नगरेका भए बौद्ध दर्शन सफल नै हुने थिएन। त्यसैले बुद्धको लचकताले गर्दा नै बौद्ध दर्शन फैलिंदै जाने र पछिसम्म पनि कायम रहने अवस्था भएको हो भन्दा अनुपयुक्त नहोला ।

मानव जगत्का सबै समस्याको समाधान आफैंमा छ आफैंभित्र खोज भन्ने बुद्ध बचन अर्थात् बौद्ध दर्शनले संसारका सबै समस्याको समाधान अर्थात् उत्तर दिन्छ भन्ने धारणा पनि पाइन्छ। जानेको बाट नजानेकोतर्फ बढ भन्ने उनले मानव शरीरमा नै सम्पूर्ण ब्रह्माण्ड समाहित छ, आफैंलाई एउटा टापु बनाउ, आफैंमा प्रकाश छर, आफैं मालिक हौ, आफैं दास हौ, यहाँ अर्को कोही छैन, आफैंले आफैंलाई जित त्यो भन्दा ठूलो जीत कुनै छैन भनी आत्म अहड्कारबाट बाहिर निस्केपछि, मात्र ज्ञान प्राप्तिको ढोका खुल्ने जनाएका छन् (गुरुजी, १९९९ : १४)। आफूलाई जति हेयो (बुक्यो) त्यति नै कति शक्तिशाली रहेछु भन्ने बुभून सकिन्छ भन्ने बुद्धले आफ्नो गहिराइ बुभके थिए। कर्म आफैं गर अरुको भर नपर भन्ने बुद्ध दर्शनको विश्लेषण गर्दा सारमा “आफैंमा भर पर्नु” रहेको भेटिन्छ। मेरो कुरालाई अन्धभक्त भएर पालना नगर, प्रश्न गर्न पनि सिक, जति प्रश्न गछों त्यति ज्ञानको उत्सुकता बढेर गहिराइ पाउँछौ भन्ने उनका उपदेशले खोजमुखि बनाउन खोजेको थाहा हुन्छ।

संसारलाई सदैव बलिरहेको देख्ने बुद्धले लोभ, कोध र मूर्खताको अग्नीले त्यस्तो भएको जनाउँदै हरेक मानिस यस्ता आपत्बाट सकेसम्म उम्कनु पर्दछ भनी पापलाई परित्याग गर्नु, असल कुराको खोजी गर्नु र मनलाई पवित्र राख्नु नै जीवन गतीको आधार बनाउन भनेका छन् (क्योकाइ, २०१५ : १५७-१६६)। मनपराएका वस्तुहरूप्रति आसक्त नहुन र मन नपराएका वस्तुलाई घृणा नगर्न भनेका उनले अशल कुरा खोजी मनलाई पवित्र राखि पापलाई परित्याग गर्न, रिस, दु:ख, लोभ परित्याग गरी विशुद्ध निस्वार्थी जीवन विताउन, आफूसँग भएको कुरामा सन्तुष्ट हुन, विश्वसनीय बन्न र अज्ञानताको परित्याग गर्नु उपयुक्त हुने जनाएर दण्ड सजायबाट समस्या 
समाधान नहुने ठहर गरेका छन् । समाजमा विकृति केबाट आउँछ, मानिस किन चोरी-डकैतीमा लागदछ् आदि तहसम्मै पुगेर प्रेमद्वारा सुधार गर्न जोड दिने ऋममा मानिसलाई अपराध, चोरी, डकैती गरेपछि दण्ड सजाय दिनुको सट्टा त्यस्ता कार्यमा लाग्ने कारण गरिबी र अभावकै अन्त गरिदिएका खण्डमा सबै बराबर भएर समाज सुध्रन्छ भनेका छन् (गुरुजी, १९९९ : १७)। अभावगरिबी हटाएको खण्डमा चोरी, डकैतीजस्ता अपराध नहुने बुद्ध दर्शन शान्ति ल्याउन सबै मिलेर विस्तारै दु:खका कारणहरू हटाउँ जानु पर्दछ भन्ने इशाई र यहुदी दर्शनसँग पनि मेल खाने देखिन्छ।

समग्रमा शाक्यमुनी बुद्धले ज्ञान प्राप्ति पछिका पैतालिस वर्षसम्म दिएका उपदेशहरूबाट निर्मित बौद्ध दर्शन समग्रमा उल्लेख गर्न खोज्नु कठिन कार्य हो । बुद्धले आफ्ना उपदेशमा प्रयोग गरेका बचनहरूले आधिकारिकता राख्ने यो दर्शनमा चौरासी हजार धर्मद्वारहरू र धेरै सम्प्रदायहरू निहित छन् । समानताको पक्षमा अत्यन्त दृढतापूर्वक वहस गरि हरेक मानिसले आफ़्नो उपदेश बुभ्क्न सकोस भन्नेमा ध्यान दिएर अन्तिम घडीसम्म पनि सरल भाषामा उपदेश दिने बुद्ध यथार्थमा अविश्रान्त यात्री नै हुन् । बुद्ध प्रदत्त वाणीहरू नै सर्वमान्य मानिएको बौद्ध दर्शन दैनिक जीवनको वास्तविकतासँग घनिष्ट नभएमा मानिसलाई भित्री हृदयदेखि नै विश्वास राख्ने प्रेरणा दिन समर्थ हुँदैन । त्यसैले अवका दिनमा यसलाई स्पष्ट भाषामा सरलसँगै गुणमा निष्पक्ष र सबैलाई प्रतिनिधित्व गर्ने पर्याययुक्त वान्छनीय शब्दहरू सहितको बनाउनु जरुरी देखिन्छ।

\section{लुम्बिनीको विकास र महत्त्व}

वर्तमान नेपालको दक्षिण-पश्चिमी तराइको रूपन्देही जिल्लामा अवस्थित लुम्बिनी प्राचीन धार्मिक महत्त्वको प्रतिनिधित्व गर्ने ग्रामिण शहरका रूपमा विकसित हुँदै आएको छ। शाक्य गणराज्य कपिलवस्तुका राजा शुद्धोदनकी रानी मायादेवीको कोखबाट यही ठाउँमा जन्मिएका सिद्धार्थ गौतमले सम्पूर्ण सुख सयल र राज्यसत्ता सहितको जीवन त्यागेर ज्ञानको खोजीमा दु:ख-कष्ट भोगदै गरेको प्रयासका अन्तमा बोधिसत्व प्राप्त गरेपछि पनि बाँकी जीवन ज्ञान प्रचार-प्रसारमै विताएका थिए। तत्कालिन समाजका विकृति-विसंगती र भेदभावपूर्ण व्यवहारनीति विपरित दया, क्षमा, करुणाको आवश्यकता बोध गराएर अनित्य, अनात्मा र दु:खबाट मुक्त भएमा निर्वाण वा मुक्ति पाइन्छ भन्ने सन्देश दिने कार्यले नै बुद्धलाई महान् बनाएको हो। महानिर्वाणपछि, उनका उपदेशहरूले बौद्ध दर्शन हुँदै बौद्ध धर्मको आधार अर्थात् धार्मिक सिद्धान्तको रूप लिन थालेपछि यिनको जीवनसंग सम्बन्धित स्थलहरू महत्त्वपूर्ण तीर्थस्थल एवं धामहरूको रूपमा विकसित हुँदै गए। जन्मदेखि मृत्यूसम्मको अवधिमा चार महत्त्वपूर्ण चरण निर्माण गरेकाले महत्त्वपूर्ण मानिएका चार स्थलहरूमध्ये नेपालको लुम्बिनी जन्मस्थल भएकाले सर्वाधिक महत्त्वपूर्ण तीर्थ स्थल बनेको छ।

लुम्बिनीमा सर्वप्रथम राजा शुद्धोदनबाट मायादेवीको मन्दीर बनाएर महत्त्वपूर्ण र प्रसिद्ध स्थल बनाउने कार्य थालिएपछि, चहल पहल बढ़दै गयो (शाक्य, २००४ : ४४)। ज्ञान प्राप्तिपछि धर्मदेशनामा लामो समय बिताएपछि, केही दिन तुषितामा बसेर वैशाली हुँदै पावानगरमा पुगेका बुद्धले चुन्द नामक नकर्मी पुत्रकहाँ अन्तिम भोज ग्रहण गरेपछि कुशिनगरस्थित शालोधानमा पुगे। महापरिनिर्वाण सूत्रका अनुसार तथागतको महापरिनिर्वाण अगाडि 
शिष्य आनन्दद्वारा उनको धर्म-दर्शन एवं समर्थकहरूका बारेमा जिज्ञासा राख्ने काम भयो। धर्मलाई आदर-श्रद्धा राखि अभ्यास सहित गरेको धर्माचरण नै परमोत्तम भएको जानकारी दिएका तथागतबाट लुम्बिनी बगैंचाको अर्थपूर्ण उद्देश्य एवं गुण स्पष्ट गर्दे आफ्ना विश्वासी समर्थकदेखि साधारण भक्तहरूलाई बोध गया सारनाथ र कुशिनगर जस्तै जन्मस्थल लुम्बिनी पनि पवित्र र महत्त्वपूर्ण रहेको जनाएर भ्रमण गरि पुण्यस्थल बनाउन सल्लाह दिए (पाण्डे, १९६४ : ४१; अमृतानन्द, १९९९ : ११३-११४; जनरल सेक्रेटरी, २००० : १३)। कपिलवस्तु एवं देवदहका युवाहरूद्वारा वन विहार, आमोद प्रमोद एवं विश्राम स्थलका रूपमा प्रयोग गर्दे आएको स्थल भएकाले बुद्धद्वारा महापरिनिर्वाणका बेला कुशिनगरबाट सवै समर्थकहरूद्वारा दर्शनीय बनाउन आदेश दिइएको हुन सक्दछ।

तथागतको महापरिनिर्वाण पछि बौद्ध अनुयायी एवं समर्थकहरूद्वारा महत्त्वपूर्ण धार्मिक स्थलका रूपमा लिएर भ्रमण एवं श्रद्धा प्रकट गर्ने कार्य थालिएपछि, लुम्बिनीको महत्त्व बढ्दै गयो। गुम्बा स्तुपाहरू बनाएर श्रद्धा प्रकट गर्ने, बस्ने परम्परा विकसित भएपछि, बौद्ध दर्शनका समर्थकहरूद्वारा पनि बनाउने बस्ने काम भयो। यसप्रकार तीर्थयात्री एवं यात्रुहरू आउने ऋम शुरु भएपछि, लुम्बिनी तीर्थयात्रा एवं पर्यटनका लागि विश्वकै रोजाइको केन्द्र बन्दे गयो। मस्तिष्कलाई शान्ति एवं परिष्करण गर्ने चाहना अनुरूप लगातार रूपमा आइरहने भिक्षु-भिक्षुणिहरूसँगै राजादेखि नोकरसम्म र पुरुषदेखि नारीहरूसम्मबाट तीर्थयात्रीका रूपमा श्रद्धासाथ भक्तिभाव प्रकट गर्ने काम भयो (वैद्य, २१ फेब्रोअरी २०२०; बिडारी, १४ फेब्रोअरी, २००२)। समयक्रममा केही हिन्दूहरूद्वारा इक्ष्वाकुवंशीय रघुपती रामका वंशबाट आएका अरू केहिद्वारा भगवान पशुपतिनाथको उत्तरी अनुहारले भगवान बुद्धको प्रतिनिधित्व गर्ने मान्दछन् भने उनलाई भगवान् विष्णु वा नारायणको नवौं अवतार मान्नेहरूको समूह पनि निकै ठूलो छ (ढकाल, २००३ : २०)। यसप्रकार ऐतिहासिक-धार्मिक आधारहरूले गर्दा हिन्दूहरूको समेत महत्त्वपूर्ण आस्था केन्द्र बनेको लुम्बिनीको खोज अध्ययन क्रममा भएका उत्वननहरूमा इ.पू. छैटों-सातौं शताब्दीतिरका पुरातात्विक अवशेषहरू प्राप्त भए तापनि ई.पू. तेस्रो शताब्दीभन्दा अगाडि उच्चतहका व्यक्तित्वहरूद्वारा दर्शन भ्रमण गरेको नभेटिई केवल अशोकको आगमनदेखिको मात्र यथार्थ इतिहास पाइन्छ।

ऐतिहासिक घटनाक्रमहरूको विश्लेषण गर्दा इशापूर्वको तेस्रो शताब्दीलाई बौद्ध दर्शन एवं लुम्बिनीको इतिहासका लागि महत्त्वपूर्ण सावित भएको शताब्दी मान्नु पर्दछ। शक्ति उन्मादले राज्य विस्तार अभियानलाई नै मूल लक्ष्य बनाएका मौर्य सम्राट अशोकद्वारा कलिंगामाथि आक्रमण गरेपछिको विनाशकारी युद्धमा महानतम नरसंहार र रक्तरंजित स्थिति देखे-भोगेपछि उत्पन्न परिणामी रूपान्तरण बौद्ध दर्शनको इतिहासमै कोशेढुंगा बनेको हो (विडारी, १४ फेबोअरी, २००२)। त्यस घटनाबाट युद्धको विभिषिका बोध गरी चण्डबाट धम्ममा रूपान्तरण भएका अशोकद्वारा साम्राज्य विस्तारको महत्त्वाकांक्षा छाडेर भारत र आसपासका क्षेत्रमा बौद्ध दर्शन फैलाउने र संरक्षण गर्ने लक्ष्य अनुरूप बढे। त्यसै क्रममा बौद्ध धामहरूको धर्मयात्रा एवं विहार यात्राहरूलाई संस्थागत गरी राज्य र राजाहरूद्वारा संचालन, बढावा र संरक्षण गर्ने कार्य शुरु भएको हो। जसको प्रमाणका रूपमा लुम्बिनी र निग्लिहवामा उपलव्ध अभिलेख सहितका र टुक्रिएको स्थितिमा प्राप्त गोटीहवा स्तम्भसँगै अशोकका छोरा 
छोरीहरूद्वारा श्रीलंकासम्मै पुगेर बौद्ध नियमबारे दिएको धर्म उपदेश विषयलाई लिन सकिन्छ, (वैद्य, २१ फेब्रोअरी, २०२०)। बौद्ध धर्मको विकास र संरक्षणमा पुच्याएको योगदानले गर्दा सम्पूर्ण बौद्धमार्गीहरूले अभिभावकदेखि बोधिसत्वसम्मकै उपाधि दिएका मौर्य सम्राट अशोकको लुम्बिनी भ्रमणबारे उनले नै लुम्बिनीमा स्थापना गरेको अभिलेख सहितको शीला स्तम्भबाट नै जानकारी पाउन सकिन्छ।

महास्थविर उपगुप्तको सल्लाह अनुरूप लुम्बिनी दर्शनका लागि आएका मौर्य सम्राट अशोकद्वारा स्थापित अभिलेख सहितको चुनार बलौटे प्रस्तर स्तम्भ (अशोक स्तम्भ) देखि नै लुम्बिनी बगैंचाको वास्तविक इतिहास शुरु हुन्छ भन्ने धारणा डा. पाण्डेको छ (पाण्डे, १९६५ : ४१ । बुद्ध धर्मग्रहण गरेपछि बुद्ध जन्मस्थल दर्शन गर्न आएका उनले सुद्धोदनद्वारा स्थापना गरिएपछि आगलागिबाट नष्ट भएको मायादेवी मन्दिर पुनर्निमाण गर्न, अशोक स्तम्भ राख्न, पोखरी लगायत चैत्य एवं विहारहरू निर्माण, पुननिर्माण गर्न स्वर्ण मुद्राहरू अर्पण गर्ने र वरपरका गाउँ क्षेत्रमा कर मिनाहा आदि कार्य गरेको पनि उल्लेख पाइन्छ (पाण्डे, १९६५ : पू१)। भ्रमण कममा बुद्ध जन्मस्थल लुम्बिनी नै किटान गरको अभिलेख सहितको चुनार बलौटे प्रस्तर स्तम्भ स्थापनासँगै भगवान बुद्धले प्रथम पाउ टेकेको स्थल भन्दै पहिचानशिला अर्थात् मार्करस्टोन स्थापना गर्ने अशोकको कार्यबाट शताब्दीयौं पछि पनि लुम्बिनीको पहिचान कसैले खोस्न-मेट्न नसक्ने गरी स्थापित भएको हो ।

अशोकको भ्रमणपछि लुम्बिनीको महत्त्व र प्रचार प्रसार बढ़न गयो । उत्तर भारत लगायतका ठाउँहरूबाट बौद्ध तीर्थयात्रीहरूदेखि भिक्षुहरूसम्मले लुम्बिनीको भ्रमण-दर्शन गर्न थाले। त्यसबाट थप उत्साहित भएका बौद्ध धर्म-दर्शनका संरक्षकहरूद्वारा भिक्षु एवं तीर्थयात्रीहरूलाई आवास लगायतका सुविधाहरू उपलव्ध गराउन विहार एवं गुम्बाहरू निर्माण गरि बुद्ध जन्मस्थलको लोकप्रियता बढाउने काम भयो। समयक्रममा उत्पन्न अवरोध, प्राकृतिक विपत्ती-प्रकोप समेतको मार सहँदै बढेको लुम्बिनीमा चिनिया यात्रीहरू आएको देखिन्छ। यस बारेमा कलम चलाउने विभिन्न व्यक्तिहरूको हवाला दिएर समग्र विवरण विश्लेषण गर्न खोजेका एक अध्येताका अनुसार लि-ताओ-युंग, सेङ-साइ, वाई यु.चिन, फाहियान, हुयनसाङ, फाङ चीन आदिले लुम्बिनी भ्रमण गरेर यात्रा विवरणमा केही न केही लेखेको विवरण पाइन्छ (महर्जन, २००४ : ४१-४५)। लुम्बिनी स्थित चिनिया गुम्बाका एक भिक्षुले फाहियान, हुयनसाङ, आदिद्वारा लुम्बिनी भ्रमण गरेको विवरणमा लुम्बिनी बगैंचामा बुद्ध जन्म विवरण, रामग्राम स्तुपामा पुगेका अशोकद्वारा अस्थिधातु निकाल्न खोज्दा त्यहाँका संरक्षकहरूले नदिएको विवरण, कपिलवस्तुको विवरण देखि लुम्बिनी बगैंचाको वर्णन, बुद्ध जन्मस्थलको पहिचान शिला, मन्दिर, अशोक स्तम्भ, पुष्करिणी पोखरी, बुद्धजन्म पहिचान वृक्ष, केही स्तुपाहरू, तेलार नदी भरिएको अवस्थामा देखे-पाएको भनि चिनिया स्रोतहरूमा उल्लेख भएको भन्दै प्रकाशित गरेका छन् (हुई, २००० : ११ - १६)। चिनिया यात्रीहरूकै विवरण उल्लेख गरेका अर्का लेखकले मानिसहरूले पुष्करिणी तलाउबाटै पिउने पानी ल्याएको, अशोक स्तम्भ टुक्रिएको अवस्थामा भेटेको देखि तेलले भरिएको तेलार नदीसम्मको विवरण पाएको जनाएका छन् (प्रधान, १९६द : १९-२६)। उल्लेखित विवरणहरू समेतका आधारमा लुम्बिनी महत्त्वपूर्ण धार्मिक तीर्थस्थल बनेको उल्लेख गर्ने प्राज्ञ-अध्यता एवं लेखकहरूबाट त्यस क्षेत्रमा शासन गर्ने राजा महाराजाहरूबाट लुम्बिनीको संरक्षण 
र व्यवस्थापनका लागि नैतिक एवं आर्थिक सहयोग गरेको, रिपु मल्लजस्ता सूर्यवंशी राजाद्वारा आक्रमण गरेर उत्तर भारतदेखि लुम्बिनीसम्मका ऐतिहासिक स्थलहरू तहस नहस पारेपछि, औरंगजेब सहितका मुगल शासकको नीति पनि त्यसै अनुरूप भएकाले हराउँै गएको लुम्बिनी जड्गलद्वारा छोपिएको स्थितिमा पुगेको मानेका छन् (पाण्डे, ४ मे २००४ : ३४; पाण्डे, १९९५ : ३९; वैद्य, २१ फेब्रोअरी २०२०)। जसले गर्दा लुम्बिनी भन्ने नामनै नसम्भने स्थिति भएपछि रुम्मिनी, रुमिनदेहि हुँदै रूपन्देही बन्न पुगेको यो ठाउँ विविध आरोह अवरोह सहँदै पछिल्लो चरणमा मायादेवीको मूर्तिलाई वनदेवीका रूपमा बलि दिएर पूजा गर्ने सम्मको स्थिति वा अवस्थामा पुगेको उल्लेख पाइन्छ।

मुस्लिम आक्रमण, प्राकृतिक प्रकोप आदिले उजाडिदै गएर जड्गलमा परिणत भएको लुम्बिनी र बौद्ध दर्शन नेपालको आधुनिककालिन पहिलो अवधिभर ओभेलमै पयो। भारतीय क्षेत्रमा आफ्नो प्रभाव कायम गरेका अंग्रेजहरूले एशिया प्रशान्त क्षेत्रका धर्म-दर्शनका नयाँ विधा-क्षेत्र खोज अध्ययन गर्ने ऋममा बौद्ध धर्म र दर्शनको अध्ययन प्रकाशन गरिदिएपछि, मात्र यो धर्म-दर्शन अन्तर्राष्ट्रिय रुची र चासोको विषय बनेको हो। भारतलाई उपनिवेश बनाएपछि स्थिति वा पकड जमाएका अंग्रेजहरूले त्यहाँका प्राचीन संस्कृति, धर्मसमेतको खोजीका लागि भारतीय पुरातात्विक सर्वेक्षण विभाग खडा गरेपछि, सर विलियम जोन्सद्वारा एशियाको इतिहास, पुरातत्त्व, कला, विज्ञान, साहित्यको विकास गर्ने उद्देश्य अनुरूप कलकत्तामा शाही एशियाली समाजको स्थापना गरि संस्थाका क्रियाकलाप भारत र छिमेकी मुलुकहरूको साँस्कृतिक पुनरुत्थान गराउनेतर्फ केन्द्रित गरे (वैद्य, २१ फेब्रोअरी २०२०; विडारी, २००३ : ६२)। भारतीय धर्म-संस्कृतिसँग सम्बन्धित परम्परागत इतिहास अर्थात्. स्थिति अध्ययनका लागि भाषा-लिपि अध्ययन जरुरी देखिएपछि शाही एशियाली समाजले त्यसतर्फ ध्यान दियो। लामो प्रयास र खोज-अध्ययन पछि सन् १६३७ मा जेम्स फिलिपले ब्राम्ही लिपिको रहस्य (ज्ञान) पत्ता लगाएकाले पाली भाषाको अपार बौद्ध साहित्य भण्डार अध्ययन सम्भव भएकाले छुट्टै अस्तित्त्व प्राप्त गरेको पुरातत्त्वद्वारा बौद्ध स्थलको जानकारी प्राप्त गरि थालेको खोज अभियान बोधगया, सारनाथ, कुशिनगरपछि मात्र लुम्बिनीको जानकारीमा पुगेको तथ्य भारतीय प्राचीन इतिहासमा पढ्न पाइन्छ (वैद्य, २१ फेब्रोअरी २०२०)। अर्कातिर भारतीय बौद्ध दर्शन-साहित्य अध्ययन ऋममै चिनिया (तिब्बती) भाषा अध्ययनमा सफलता पाएका सर अलेक्जेण्डर कनिड्घमले चिनिया यात्रीहरूका वृतान्तका आधारमा बौद्ध-स्थलहरूको अध्ययन-अन्वेषण थालेपछि, लुम्बिनी, कपिलवस्तु, देवदह, रामग्राम आदि स्थलहरूको विवरण भेटे (विडारी, २००३ : ६२)। त्यसपछि मात्र पुरातात्विक अध्ययनमा लागेका यूरोपियनहरूले भारतीय क्षेत्रभन्दा वाहिर पनि बौद्ध दर्शन सम्बन्धित स्थलहरू रहेकोमा विश्वस्त भएर दायरा फराकिलो पार्नेतर्फ लागे।

विदेशीहरूलाई सजिलै प्रवेश नदिने राणाकालिन नेपालको नीतिले गर्दा आउन नपाएका अंग्रेजहरूले बोधगया, कुशिनगर, सारनाथ जस्तै लुम्बिनी-कपिलवस्तु आदि पानि भारतको उत्तर प्रदेशमै होला भनी त्यतै खोज्ने गर्दे थिए। वर्तमान भारतको सिद्धार्थनगर केन्द्रित खोजीबाट खासै उपलब्धि नभएपछि, चिनिया लिपि विज्ञ लासेन समेतको सहयोगमा थालेको खोजले रोहिणी नदी किनारी क्षेत्रमा कपिलवस्तु हुनुपर्ने संकेत दियो। लामो समय 
लगाएर गरेको खोज पनि सार्थक हुन नसकेका बेला जेम्स प्रिन्सेफ र अलेक्जेण्डर कनिङ्घमद्वारा अशोकन ब्राम्ही लिपिको अध्ययन गरेर "दि एनसियन्ट जोग्राफि अफ इण्डिया" नामक पुस्तक प्रकाशित गरेपछि प्राचीन बौद्धकालिन कार्यबारे पनि अध्ययन भएकाले कपिलवस्तु र लुम्बिनी हिमालयभन्दा तलको चुरे पर्वतको आधार तहमा अवस्थित रहेको स्पष्ट भयो (पाण्डे, $\curlyvee$ मे. २००४ : ३५)। भारतीय क्षेत्रमा स्थापित साम्राज्यमा पकड कायम राख्न हरेक क्षेत्रलाई रेलमार्गसँग जोडेर स्थिति बलियो पार्न चाहेका अंग्रेजहरू रेलमार्ग विस्तारमा लागेका थिए । रेलमार्गको लिकमा ओछ्रयाउन सालका विशाल रुखबाट निर्मित स्लिपर चाहिएपछि, नेपालसँग किन्न चाहेका अंग्रेजहरूले सम्पर्क- कुराकानी गरे। जड्गल बेचेर पैसा कमाउने मौका देखेका राणाहरूले पानि उक्त प्रस्ताव मानेर नेपालको तराइ क्षेत्रको घना जड्गल काट्ने ऋम शुरु भयो । त्यसै ऋममा वीर शमशेरद्वारा पाल्पाको वडाहाकिम बनाएर धपाइएका खड्ग शमशेरले लुम्बिनी क्षेत्रमा थालेको जड्गल कटान कार्य नै लुम्बिनी भेट्टाउने कारण बन्यो (वैद्य, २१ फेब्रुअरी २०२०; सुवेदी, २४ नोभेम्वर २०१६)। काममा खटिएका कामदारहरूबाट रुम्मिनदेहिको जड्गलभित्र ढुंगाको स्तम्भ रहेको समाचार पाएपछि, आफै पुगेका खड्ग शमशेरले माटो पन्छाउन लगाइहाले ।

अर्कातिर लुम्बिनी-कपिलवस्तु खोजी कार्यमा लागि रहेका डा.ए. फुहररलाई पनि भारतको वस्ती जिल्लाको उत्तरी सिमापारी नेपाल तराइको पुरातात्विक सम्भावना खोज्नका लागि पठाइएको थियो (पाण्डे, $\checkmark$ मे २००४ : ३५) । १६९३ मा मेजर जसकरण सिंहले नेपाल तराइमा अभिलेख सहितको शिलास्तम्भ देखेको प्रकाशित गरेपछि, हिँडेर १६९५ मा निगिलहवास्थित अशोक स्तम्भ पत्ता लगाइसकेका फुहरर लुम्बिनी जड्गलको लोकेसन पछ्याउँदै बढेर १६९६ डिसेम्वर $१$ का दिन खड्ग शमशेरद्वारा माटो पन्छाउने कार्य सक्नै लागेका बेला टुप्लुक्कै पुगेपछि लुम्बिनी खोजी अभियान सार्थकता उन्मुख भयो (रिजाल, १९६३: १६; महर्जन, २००४: १०४)। सम्पूर्ण माटो पन्छाइसकेपछि, लुम्बिनीको अशोक स्तम्भमा रहेको लिपि उतार्ने, फोटो खिच्ने गरेका फुहररले अर्का जर्मनी विद्वान. ब्राम्ही लिपि विशेषज्ञ इ. हुल्जको सहयोगमा पढेपछि लुम्बिनी नै गौतम बुद्धको जन्मस्थल भएको प्रमाणित भएकाले थप अध्ययन एवं खोज शुरु भयो। बावु पूर्णचन्द्र मुखर्जी, श्रीमती देवला मीत्र आदिका खोज उत्वननबाट अशोक स्तम्भ, पुष्करिणी तलाउ, मायादेवीको मूर्ति, चारवटा चैत्यहरू लगायत धेरै पुरातात्विक महत्त्वका वस्तुहरू प्राप्त भएपछि कपिलवस्तुको समेत खोजी, अध्ययन उत्वनन गरेर महत्त्वपूर्ण मान्यता स्थापित गरिएको थियो (विडारी, १४ फेब्रोअरी, २००२; विडारी, मे १९९६ : १०-३२)। यसप्रकार स्पष्ट अभिलेख सहितको अशोक स्तम्भ भेटिए पछि १९३३- १९३९ को अवधिमा केशर शमशेरको नेतृत्वमा पुन: विस्तृत कार्य भयो। अवस्थित पुराना संरचनाहरूको उत्वनन-व्यवस्थापन गरेका उनको कुनै प्रतिवेदन नभेटिए तापनि प्राचीन संरचनाको अध्ययन संरक्षणदेखि मायादेवी मन्दिरको जिर्णोद्वार, पुष्करिणी तलाउ व्यवस्थापन, इनार मर्मत, ढिस्काहरूभित्र पुरिएका संरचना उत्वनन् गरि काम गरेको साल अंकित ईंटाद्वारा छोप्ने काम गरेको उल्लेख पाइन्छ (महर्जन, २००४ : ११२-१२१)। त्यसपछिको समयमा राणाशासनद्वारा लुम्बिनीको महत्त्व बुक्के खासै कार्य नगरिएपछि, आसपासका क्षेत्रमा बस्न थालेका मानिसहरूद्वारा अतिक्रमण थालेर कतिपय महत्त्वपूर्ण सम्पदा-वस्तुहरू नष्ट 
गर्नेदेखि मायादेवीको मूर्तिलाई वनदेवीको नामले पूजा गर्ने सम्मका गतिविधि गरिदै गयो। परिणामस्वरूप बुद्ध जन्मस्थलबारे भ्रम फैल्याउन खोज्ने सम्मको परिस्थिति पनि बढ्न थाल्यो ।

वैदेशिक जगतमा नेपालबारे खासै जानकारी नभएका बेला खड्ग शमशेरबाट अशोक स्तम्भको उत्खनन र जर्मन पुरातत्त्वविद्हरूबाट लिपिसमेतको अध्ययन प्रकाशन पछि, लुक्बिनीको महत्त्व बढ़न गयो। राणाकालिन स्थितिमा केशर शमशेरको उत्वनन् संरक्षण पछिको अवस्थामा खासै ध्यान नदिइनाले अन्य उल्लेखनीय कार्य हुनै सकेन । १९५०-१९५१ को कान्तिद्वारा राणाशासन समाप्त गरिएपछि सर्वप्रथम त्यसतर्फ ध्यान दिएका राजा त्रिभुवनबाट रु.१०,०००।- (दशहजार) को व्यवस्था गरेर वडाहाकिमको नेतृत्वमा विकास कार्य थालनी गरेको उल्लेख पाइन्छ, (वज्राचार्य, नोभेम्बर- डिसेम्बर २००४ : १६)। नेपालको राजनीतिमा महत्त्वपूर्ण व्यक्तित्वका रूपमा स्थापित गणेशमान सिंहबाट सशस्त्र कान्ति सफल भएर प्रजातान्त्रिक व्यवस्थाको शिलान्यास भएपछि, संक्रमणकालमा पश्चिम नेपालको भ्रमणमा जाँदा लुम्बिनी पुगेर सरकारी गेस्ट हाउसमा बसी गरेको अवलोकन ऋममा पाएको अस्तव्यस्त अवस्था र मायादेवीको मूर्तिमा बली चढाएर पूजा गर्ने स्थिति देखेपछि, फर्केर राजा त्रिभुवनलाई जानकारी गराएपछि १९५२ को अन्ततिरबाट वडाहाकिम अन्तर्गत विकास कार्य थालिएको जानकारी १९६द को जनवरीमा सँगसँगै लुम्बिनी भ्रमणमा जाँदा पंतिकारलाई दिइएको थियो (सिंह, १९६६ जनवरी)। राजा त्रिभुवनको अग्रसरतामा शुरु भएको लुम्बिनी संरक्षण-व्यवस्थापन कार्यलाई उनका उत्तराधिकारीहरूले संस्थागत स्वरूप दिएकाले कमश: प्रगतिउन्मुख स्थिति विकसित भएको हो ।

१९६० को कदमपछि सर्वशक्तिमान बनेका राजा महेन्द्र जनताको भावनासँग प्रत्यक्ष जोडिएका पशुपतिनाथ एवं लुम्बिनीको विकासमा लागि परे। १९५६ नोभेम्वर १५-२१ सम्म काठमाडौंमा आयोजित चौथो विश्व बौद्ध भ्रातृत्व सम्मेलनले बुद्ध जन्मस्थलको संरक्षण र विकासका लागि आवाज उठाएपछि, रु. २१,००,०००।- (एक्काइस लाख) रूपैया प्रदान गरि मायादेवी मन्दीरको जिर्णोद्धार भैरहवा लुम्बिनी सडक र विहार निर्माणको प्रबन्ध गरे (bodhitv. tv $>$ article) । उनको निर्देशनमा विभिन्न राष्ट्रिय अन्तर्राष्ट्रिय संघ-संस्थाहरूको सहयोग र सहकार्य जुटाउन सक्रिय भएको सरकारले लुम्बिनीको संरक्षण, उत्वनन र सम्वर्द्धनका लागि केही निकायहरू बनाएर पहल थाल्ने र संयुक्त राष्ट्र संघ समक्ष कुरा पुच्याउने प्रयास थाल्यो (वज्रंचार्य, ३१ मार्च १९९९)। लुम्बिनीको स्थिति अवगत गराएर सहयोग जुटाउने कममा थालेका प्रयासले सकारात्मक प्रभाव पारेकाले संयुक्त राष्ट्र संघसँगै विभिन्न अन्तर्राष्ट्रिय संघ संस्थाहरू सहयोग सहकार्यमा आए। त्यसै ऋममा १९६७ अप्रिल २३ मा संयुक्त राष्ट्र संघका महासचिव उथान्त लुम्बिनी भ्रमणमा आएपछि देखेको स्थिति र अवस्थाले गर्दा भाव विभोर भए। बुद्ध दर्शनका सच्चा अनुयायी उनी हृदयदेखि नै दुखि भएर पवित्र भूमिसँग क्षमा मागदै फर्किएपछि अन्तर्राष्ट्रियकरण गरैरै पनि लुम्बिनीको विकास गर्ने पक्षमा पुगे (गुरुङ, १९९९ : २५)। राजा महेन्द्रसँग त्यसबारेमा कुरा गरेका उनले राजाको सहमति पाएपछि विश्व शान्तिका लागि लुम्बिनीलाई महत्त्वपूर्ण धार्मिक केन्द्रका रूपमा विकास गर्न अन्तर्राष्ट्रिय समुदायसँग आह्वान गरे। महासचिव उथान्तको भ्रमणको करिव ६ महिनापछि, अक्टुवर १९६७ मा महासचिवसँग भेट्न पुगेका नेपालका उपप्रधानमन्त्री र परराष्ट्र मन्त्रीद्वारा लुम्बिनीको व्यवस्थित विकासका लागि 
गुरुयोजना अर्थात व्लू प्रिन्ट बनाइ दिनका लागि नेपाल सरकारका तर्फबाट औपचारिक अनुरोध गर्ने काम भयो (सेक्रेटरी जनरल, २००० : ३७)। नेपाल सरकारको औपचारिक अनुरोधपछि, १९६७ डिसेम्बरदेखि १९६६ जनवरी सम्मको अवधिमा संयुक्त राष्ट्रसंघ मिशनको तिन सदस्यिय टोलीले नेपाल भ्रमण गरी यातायात, खानेपानी, विद्युत, आवास आदि अत्यावश्यक प्रारम्भिक सुविधाहरूबारे सल्लाह सुकाव दियो ।

महासचिव उथान्तको अग्रसरतामा चलेको करिव ३ वर्षको गृहकार्य पछि १९७० मा संयुक्त राष्ट्र संघका लागि नेपालको प्रतिनिधिको संयोजकत्वमा शुरु गरिएको छलफलका अन्तमा भारत, वर्मा, अफगानिस्तान, जापान, कम्पुचिया, इण्डोनेशिया, श्रीलंका, थाइल्याण्ड, पाकिस्तान, सिंगापुर, मलेशिया, लाओस, गरि १३ राष्ट्रका प्रतिनिधिहरू सम्मिलित लुम्बिनी विकास समिति गठन गरि कार्य थालिएपछि भुटान, गणतन्त्र कोरिया र बंगलादेश पनि सामेल भएकाले अवस्था राम्रो हुँदै गयो (वैद्य, २१ फेबोअरी २०२०)। लुम्बिनीको विकासका लागि संयुक्त राष्ट्र संघ विकास कार्यक्रम अन्तर्गत लाखों डलर खर्च गरेको राष्ट्र संघले प्रशस्तै इन्जिनियरिड़ एवं पुरातात्विक अध्ययन गराएपछि, व्यवस्थित योजनाको टुझो गयो। केही चरणका छलफल एवं गृहकार्यका अन्तमा सबैजसोबाट लुम्बिनीको व्यवस्थित विकासका लागि विस्तृत गुरुयोजना तयार गर्ने निश्चय गरि संयुक्त राष्ट्र संघलाई अनुरोध गरियो। आफ्नो पहलमा थालिएको प्रक्रिया निश्चित निचोडमा पुगेपछि उत्साहित संयुक्त राष्ट्रसंघका महासचिव उथान्तद्वारा गुरुयोजना निर्माणका लागि विश्व प्रसिद्ध जापानी वास्तुविद् प्रा. केन्जो टाँगेलाई चयन गरि जिम्मा दिने काम भयो (कनिङघम, आचार्य र डेभिस, २०१६ : १०७)। यसप्रकार लुम्बिनीको व्यवस्थित विकास एवं संरक्षणका लागि विश्व जगतद्वारा हातेमालो गर्ने अवस्था-स्थिति निर्माणको थालनी भयो।

अर्कातिर नेपालभित्र पनि १९७० मै भौतिक योजना तथा सार्वजनिक निर्माण विभाग अन्तर्गत लुम्बिनी विकास परियोजना गठन गरी सम्बन्धित मन्त्रालयकै मन्त्री पदेन अध्यक्ष हुने व्यवस्था गरेर विभिन्न क्षेत्रका मानिस एवं पदाधिकारीहरू संलग्न गराउने कार्य शुरु भएको थियो (शर्मा, २६ मार्च २०२०)। लुम्बिनीको संरक्षण एवं विकासको जिम्मेवारी पाएको उक्त परियोजनाले राजाको निर्देशन अनुरूप काम थालनी भएको सानो सरकारी गेष्ट हाउसलाई सकेसम्म व्यवस्थित गर्ने, केही थप कर्मचारी व्यवस्था गरी बगैंचा व्यवस्थापनदेखि सुरक्षासम्मको प्रबन्ध मिलाउने, व्यवस्थित गुरुयोजना निर्माणका लागि संयुक्त राष्ट्रसंघ अन्तर्गत आउनेहरूलाई आवश्यक सहयोग उपलव्ध गराउने काम गरेको जानकारी लोकदर्शन बज्राचार्यले दिनु भएको थियो। थालिएका कार्यहरू व्यवस्थित बनाउन वास्तुविद् प्रा. केन्जो टाँगेद्वारा गुरुयोजनाको खाका कोर्ने ऋममा नेपाल सरकारले जग्गा जमिन सहितका विषयवस्तुहरूबारे ठोस निर्णय लिनु परेपछि, १९७५ मा लुम्बिनी विकास समिति गठन गरी लोकदर्शन बज्राचार्यलाई अध्यक्ष बनाई संरक्षण-विकास सम्बन्धित सबै कार्यको जिम्मेवारी दिइयो (शर्मा, २७ मार्च २०२०)। राजाद्वारा नै बोलाएर आफ्ना पिताको विश्वासपात्र एवं अनुभवी भन्दै प्रभावकारी काम हुने विश्वास गरेर जिम्मेवारी दिएपछि, खुसीसाथ कार्य थालेका वज्राचार्यले बन्दे गरेको गुरुयोजनालाई अन्तिम रूप दिन सघाउने, व्यवस्थित विकासका लागि जग्गा अधिग्रहण योजना, बाटो-घाटो, पानी-बिजुलीसम्मको व्यवस्था मिलाउने काम थाले (वज्राचार्य, ३१ मार्च १९९९)। तत्कालिन श्री $y$ को सरकारद्वारा दान दातब्य, विकास र 
पूर्वाधारको व्यवस्थापन मिलाउने र विदेशी नियोगहरूले योजना निर्माण गर्ने भन्ने भएपछि राजा वीरेन्द्रसमेतको सक्रियतामा बढेको कार्य उपलव्धिमूलक बनेको हो ।

गुरुयोजना निर्माण ऋममा धेरै पक्षमाथि विचार गरेका वास्तुविद् प्रा. केन्जो टाँगेद्वारा पवित्र अर्थात् धार्मिक बगैंचा, सांस्कृतिक केन्द्र अर्थात् मोनाष्ट्रि (गुम्बा) क्षेत्र र नयाँ लुम्बिनी गाउँ गरि तिनवटा मुख्य अवयवको अवधारणा राखेको पाइन्छ। उत्तर-दक्षिण लम्बवत हुने गरि बनाइएको गुरुयोजनाको उत्तरमा लुम्बिनी गाउँ र साँस्कृतिक केन्द्र व्यवस्था गरेपछि दक्षिणमा धार्मिक वा पवित्र बगैंचालाई केन्द्रीत गरि यी दुबैको बीचमा गुम्बा परिक्षेत्रको व्यवस्था गरेर बीचमा एक पैदल मार्ग सहितको नहर प्रणाली निर्माण गरि एक-अर्कालाई जोडेर सम्पूर्ण विकास गर्ने प्रवन्ध गरेका हुन् (गुरुड, १९९९ : २५)। भगवान बुद्धको जन्मकालिन समयमा जस्तै शान्ति, सार्वभौमिकता र स्पष्टता सहितको निर्मल वातावरणको संगममा पुगेको आभास गराउने कुरालाई ध्यान दिएर तयार गरिएको वृहद् लुम्बिनी गुरुयोजनामा एकान्त, पवित्रता-आनन्दी वातावरण सहितको धार्मिक बगैंचा स्थापना गरेर सानदार हिमालयको चित्रमाला जस्तै दृश्य प्रदान गरी तीर्थयात्री एवं पर्यटकहरूलाई समय र ठाउँको प्राप्तिद्वारा आनन्दित हुँदै पवित्र धार्मिक बगैंचाको पहुँचमा पुच्याउने सोच राखिएको छ (गुरुड, १९९९ : २५-२६; पाण्डे, ४ मे २००४ : ४३)। यस्ता धेरै पक्षहरूमाथि ध्यान दिइएको गुरुयोजना बारे प्रशस्त बहस-छलफल भएपछि, प्राप्त सुकावहरूलाई सुधारात्मक पक्ष भन्दे नेपाल सरकारले संयुक्त राष्ट्र संघमा पठायो। त्यसपछि जापानको टोकियोमा १९७द मार्चमा आयोजित निर्णायक बैठकमा परियोजनाका धेरै आवश्यकताहरूको निर्धारण, पुरातात्तिक कार्यहरू, मार्च १९७७ मा काठमाडौंमा आयोजित त्रिपक्षिय बैठक, स्थलगत तथ्याड्कहरूको अध्यावधिकरण, प्राविधिक महत्त्वका अन्य निर्णयहरू आदि दायित्व ग्रहण गरी गुरुयोजनालाई अन्तिम रूप दिने काम गरेको उल्लेख पाइन्छ (वज्राचार्य, ३१ मार्च १९९९)। विभिन्न राष्ट्रिय-अन्तर्राष्ट्रिय निकायहरूद्वारा भूमिगत पानी, माटो परीक्षण, निकास प्रणालीको अवस्था र आवश्यकताबारे अध्ययन समेत गरेपछि लुम्बिनी विकास गुरुयोजना स्वीकार गरेर कार्यान्वयन चरण शुरु गर्न मार्ग प्रसस्त गर्ने काम भएको थियो ।

लुम्बिनी विकास गुरु योजना तयार भएपछि, कार्यान्वयनका लागि जग्गा अधिग्रहण प्रक्रिया थालियो । विश्वकै नमूना स्मारकका रूपमा विकास गर्न खोजिएको हुँदा साढे एघार हजार विगाहा जग्गा अधिग्रहण गर्नुपर्ने भएपछि, केही खिचातानी पनि शुरु भयो। बहालवाला सम्बन्धित सचिवद्वारा नै यत्रो जग्गा किन चाहियो भन्दै अवरोध सिर्जना प्रयास गरेको बेला लुम्बिनीको विकास निर्माण कार्य अबिलम्ब गर्न शुरुदेखि नै हुकुम दिएर बेला बखतमा कार्यस्थलको स्थितिबारे के हुँदै छ भनी जिज्ञासा पनि राख्दै आएका राजा वीरेन्द्रबाट जग्गा अधिग्रहण गाह्रो काम भएकोले जनताको भावनामा ठेस नलाग्ने गरि शुरु गरिहाल्नु पर्दछ भनी उत्साहित पारी काम फत्ते गर्ने वातावरण तयार पारिएपछि, कार्य व्यवस्थित हुन पुग्यो (वज्राचार्य, नोभेम्बर-डिसेम्बर २००४ : १६-१७)। परिणामस्वरूप अधिग्रहण पूरा गरि उत्तरदेखि दक्षिणसम्म लम्बवत फैलिएको तीन स्क्वायर माइल खाली जमिन पाएपछि भैरहवा-लुम्बिनी सडक र पुल निर्माणका लागि निकै भागदौडसँगै ६ लाख विरुवा रोपेर बचाउने ऋममा पानी बोक्दै राख्दैसम्म गरे/गराएका लोकदर्शन वज्राचार्यले कार्य थालेको करिव २४ वर्ष पछि, कोरियन मन्दीरको 
धर्मशालामाथिको कौसीबाट हराभरा लुम्बिनी परिसर हेरेदे र देखाउँदै अन्तर्वार्ता दिने ऋममा अत्यन्त भावुक भएर बिर्सन नसक्ने घटना भन्दै पड्किकारलाई सविस्तार जानकारी गराएका हुन् ।

विकासको प्रारम्भिक चरणमा पुरातत्त्व विभागलाई अनुमति दिइएकाले बावुकृष्ण रिजालको नेतृत्वमा भएको उत्वनन् कार्यले प्राचीन लुम्बिनी गाउँ पहिचान गरी माटोको पर्खाल, टेराकोटाको इनार, मानव चिहान आदि सामग्रीहरू प्राप्त गरी थप अध्ययनको आवश्यकता स्पष्ट गय्यो (रिजाल, ३० मार्च १९९९)। मन्त्रालयदेखि दरबारसम्म कुरा पुच्याएर अनुमति जुटाउनु पर्ने त्यो कालखण्डमा सबै प्रक्रिया पुच्याउँदासम्ममा थप व्यवस्था नभएर महत्त्वपूर्ण अवशेषहरूको क्षति हुने-हराउने स्थिति भएपछि, लोकदर्शन वज्राचार्यलाई भेटेका उनले सबै कुरा अवगत गराए। त्यसबाट प्रक्रिया छिटो भएकाले पुनः उत्वनन संरक्षणमा जुटेका रिजालले मायादेवी मन्दिर परिसरमा केही उत्वनन सँगै स्तुपहरूको संरक्षण, अशोक स्तम्भको संरक्षण-मर्मत गरेर परिसर भित्रका साँस्कृतिक सम्पदाहरूलाई जानकारीमा ल्याउने काम गरे (रिजाल, ३ मार्च १९९९; पाण्डे, ४ मे २००४ : ३६-३७) । परिणामस्वरूप लुम्बिनी क्षेत्रको चिनारी स्पष्ट हुने आधार तयारीसँगै विकासका रेखाहरू कोरिन थाले। मायादेवी मन्दिर परिसरको विकास संरक्षणका लागि त्यही नजिकै प्रशासनिक कार्यालय राखेको लुम्बिनी विकास समितिले त्यसपछि गुरु योजना कार्यान्वयनमा ध्यान केन्द्रित गयो ।

बुद्ध जन्मस्थलका रूपमा प्रचार कार्य बढेपछि, दर्शनका लागि देश विदेशबाट बौद्ध भिक्षुहरू, विद्वान्, उपासक, उपासिका, आदिको आवागमन बढ़दै गयो। गुरुयोजना निर्माण अगावै चलेको आवागमन ऋममा श्रीलंकामा अध्ययन समेतमा २० वर्ष विताएर नेपाल फर्किएपछि धर्मोदय सभा सहितका बौद्ध संस्थाहरूको आग्रहमा लुम्बिनी राजकीय विहारका आवासीय भिक्षु बनेका भिक्षु विमलानन्दले आगन्तुक भिक्षु-उपासकसम्मलाई धर्मशालामा आवास-भोजनको व्यवस्था गरेर बुद्ध जन्मभूमिको प्रभाव बढाउने काम गरे (शाक्य, ३० मार्च १९९९)। श्रीलंका, वर्मा, थाइलैण्ड लगायतका देशहरूबाट भगवान बुद्ध जन्मभूमि दर्शनका लागि आउने तीर्थयात्रीहरूलाई राजकीय बुद्ध विहारमा शिल प्रदान गर्नेदेखि सिंहली र अन्य भाषामा बुद्ध बचन सुनाई बौद्ध दर्शन फैलाउने कार्यमा समर्पित भएर लागेका यिनले मायादेवी मन्दिर र लुम्बिनी राजकीय बुद्ध विहार बाहेक अन्य दर्शनीय-आश्रयस्थल नभएको अवस्थामा जानकारी-आश्रय दिएर लुम्बिनी एवं नेपालकै महत्त्व बढाएको उल्लेख पाइन्छ (शाक्य, "त्रिशुली" (स.), २००४ : २४-४४)। लुम्बिनीमा विकासको व्यवस्थित रूपरेखा नकोरिदैदेखि राजकीय बौद्ध विहार र भन्ते बिमलानन्दले गरेको कार्य र पुय्याएको योगदान लुम्बिनीको विकासमा कोसेढुड़ा नै भएको छ।

संयुक्त राष्ट्रसंघ जस्तो निकायको प्रेरणा, व्यवस्थापनमा थालिएको लुम्बिनी विकासले गति लिंदै गयो । मित्रराष्ट्रहरूको सहयोग बढ़दै गएपछि गुरु योजना कार्यान्वयन प्रगतितर्फ बढेकाले संयुक्त राष्ट्रसंघद्वारा योगदानलाई निरन्तरता दिने काम भयो। गुरुयोजना कार्यान्वयनमा ठूलो रकम खर्च हुने भएपछि, एक्कासि थप गृहकार्य थालेको तत्कालिन श्री $y$ को सरकारले राजा संरक्षक रहने व्यवस्था सहितको लुम्बिनी विकास कोष ऐन नै तयार गरि २०४२ साल भाद्र १३ गते लालमोहर लगाएर राजपत्रमै प्रकाशित गरि कार्यान्वयनमा ल्यायो (http://www.molipa...pdp:9) । तत्कालिन अधिराजकुमार अर्थात् राजाका भाई ज्ञानेन्द्र शाहले अध्यक्षता गर्ने 
गरी बनाइएको उक्त ऐनमा श्री $y$ को सरकारका प्रमुख सचिव, कानून तथा न्याय, शिक्षा तथा संस्कृति, निर्माण तथा यातायात आदि मन्त्रालयका सचिव, नेपाल साँस्कृतिक तथा प्राकृतिक सम्पदा संरक्षण संघका उपाध्यक्ष, धर्मोदयसभाका अध्यक्ष, राजाका उपप्रमुख सचिव पदेन सदस्य रहने व्यवस्थासँगै परराष्ट्र उपसचिवलाई सदस्य सचिवको जिम्मेवारी तोकेको पाइन्छ। नेपालमा विदेशी नियोग मित्रराष्ट्रहरू अन्तर्राष्ट्रिय संघ संस्थाहरूबाट आउने दान, दातव्य, चन्दा, लगानीबाट चल्ने विकास निर्माणका परियोजना एवं स्मारकहरूको प्रमुखमा राजपरिवारकै प्रत्यक्ष संलग्नता अर्थात् कुनै न कुनै सदस्य रहने पञ्चायतकालिन नेपाली परम्परा अनुसार लुम्बिनी विकास गुरुयोजना कार्यान्वयन चरणमा राजाकै भाई ज्ञानेन्द्रलाई हाकिम बनाएर स्वार्थसिद्ध गर्ने प्रयासमा तत्कालिन सत्तासिन सुविधाभोगी वर्गहरू सफल भएको पाइन्छ।

प्रस्तावनामै लुम्बिनीको विकास गर्ने लक्ष्य रआदर्शलाई बढ़ी प्रभावकारी बनाउने श्री $y$ को सरकारको कटिबद्धतालाई विश्व जनसमक्ष प्रस्तुत गर्न र लुम्बिनी विकास योजनालाई त्यसै अनुरूप बढ़ी समन्वयात्मक र सुचारु रूपले सन्चालन गर्ने भन्ने किटान नै गरेर ल्याइएको लुम्बिनी विकास कोषले गुरुयोजना कार्यान्वयन अगाडि बढायो। अधिग्रहण गरेर छुट्याइसकिएको तीन स्क्वायर माइल जमिनमा लुम्बिनी गाउँ, आश्रित क्षेत्र र धार्मिक उद्यानको प्रबन्ध गरी बीच खण्डको आश्रित क्षेत्रको करिव मध्य भागमा दुबैतर्फ पदमार्ग सहितको केन्द्रीय नहर प्रणाली सहितको संरचना रूपरेखा अगाडि बढाइयो (विडारी, १४ फेब्रोअरी २००२; शाक्य, ३० मार्च १९९९)। अन्तर्राष्ट्रिय शान्ति वर्षको अवसरमा १९६६ देखि अखण्ड शान्ति दीप बाल्न थालिएको लुम्बिनीलाई विश्वकै नमूना धार्मिक स्थल बनाउन खोजि दर्शन भ्रमणमा आउनेहरूका लागि सुविधायुक्त आश्रयस्थलहरू, खानेकुराका पसलहरू, धर्मशालाहरूको व्यवस्थासँगै पूजा, प्रार्थना, ध्यान गर्न उपयुक्त बनाएर अध्ययन सुविधा उपलव्ध गराई विश्व शान्ति, मानवता र मुक्तिको कामना गर्ने अवसर आदिको व्यवस्था गर्ने नीति अनुरूप कार्य अगाडि बढ्यो (शर्मा, २७ मार्च २०२०; वैद्य, २१ फेब्रोअरी २०२०)। पवित्र धार्मिक बगैचा अन्तर्गत मायादेवी मन्दिरसँगै अशोक स्तम्भ सहितका पुरातात्विक संरचनाहरू राखेर चारैतिर जलासय सहितको पोखरी बनाएपछि, त्यस निकट हरियाली बनभित्रको केन्द्रमा पदमार्ग सहितको केन्द्रीय नहर प्रणाली पछि, जमिनका ४१ टुक्रा अर्थात् प्लट छुट्याएर धार्मिक विहार, गुम्बा, ध्यान, योग केन्द्र, सभागृह, पुस्तकालय, अनुसन्धान केन्द्र, सड्ग्रहालय आदिका लागि विभिन्न राष्ट्र एवं संघ-संस्थाहरूलाई प्रदान गर्ने नीति नियम बनाइयो। जसबाट लुम्बिनी विकास गुरुयोजना परिणाममुखी कार्यान्वयन चरणमा प्रवेश गरेको प्रष्ट भयो ।

१९९० को जनआन्दोलनबाट पञ्चायती व्यवस्था समाप्त गरिएपछि, प्रचलित शासकीय परम्पराहरूको पनि अन्त गरियो। पहिलो आम चुनाव सम्पन्न भएर १९९१ मेमा गठित जननिर्वाचित सरकारले विकास निर्माणका कार्यहरूमा जनसहभागिता पुय्याउन राज परिवारको क्रियाशिलता घटाउने संवैधानिक व्यवस्था अनुसार काम शुरु गय्यो। त्यसै क्रममा लुम्बिनी विकास कोष ऐनमा संशोधन गरि प्रधानमत्त्रीलाई संरक्षक बनाएर युवा खेलकुद तथा संस्कृति मत्त्रीको अध्यक्षतामा सरकारले मनोनित गरेकाहरू उपाध्यक्ष, कोषाध्यक्ष, सदस्य सचिव र विभिन्न क्षेत्रको प्रतिनिधित्व गर्नेहरूमध्येबाट मनोनित १२ जना सदस्य सहितको लुम्बिनी विकास परिषद् गठन 
गरी लुम्बिनी विकास कोष सज्चालनको प्रबन्ध मिलाइयो (लुम्बिनी विकास..., १९९४ : ३-४)। परिषद्को प्रबन्ध एवं व्यवस्थापनमा सक्रिय भएको लुम्बिनी विकास कोषबाट जनसहभागिता समेतको ख्याल गरेर बढाइएको विकास कार्य पूर्वाधार निर्माण, अनुगमन, अन्य बौद्ध क्षेत्रहरूको संरक्षण-रेखदेखसँगै अन्तर्राष्ट्रिय सभा, सम्मेलन, सेमिनार आयोजना गर्ने भाग लिनजाने गर्दे महत्त्वपूर्ण अभिलेख तयार गर्ने अन्तर्राष्ट्रिय तीर्थयात्री एवं पर्यटकहरू बढाउने, सहयोग-समर्थन जुटाउनेतर्फ केन्द्रित भयो। त्यसै ऋममा विश्व बौद्ध राष्ट्रहरूको सहयोगमा ताइवानमा आयोजित साधारण सम्मेलनमा लुम्बिनी विकास कोषलाई पनि आमन्त्रण गरियो। १९९२ को उक्त सम्मेलनमा लुम्बिनी विकास परियोजनाका मूल्य-मान्यता अनुरूप मोनाष्ट्र, ध्यान एवं अध्ययन केन्द्रहरू बनाउनका लागि गुरुयोजनाको व्यवस्थापन अनुरूप निर्धारित प्लटहरू वितरण गरिने सम्पूर्ण विवरणहरू समेटिएको प्रतिवेदन पेश गयो (विडारी, १४ फेब्रोअरी २००२)। मोनाष्ट्रि एवं स्मारकहरू निर्माणका लागि निर्धारित उपनियमहरू पनि तत्कालैजसो प्रकाशित गरिएपछि विभिन्न बौद्ध मुलुक एवं संघ-संस्थाहरूद्वारा प्रक्रिया पूरा गरी नियमानुसार प्लटहरू प्राप्त गरि मोनाष्ट्रि लगायतका स्मारकहरू बनाउने ऋम शुरु भएर अगाडि बढेकाले लुम्बिनी अन्तर्राष्ट्रिय बौद्ध समुदायको सानो इकाइका रूपमा विकसित हुँदै आएको हो ।

विश्वकै प्रमुख धार्मिक स्थलका रूपमा परिचित लुम्बिनीको मायादेवी मन्दिरलाई जनरल केशर शमशेरले नयाँ स्वरूप दिएर बनाएपछि खासै ध्यान दिनु परेको थिएन। समयक्रममा त्यसको पछाडिपट्टिको पर्खालमा उम्रिएको पिपलको बोट हुर्किएर जराहरूले भित्रैसम्म पुगेर सम्पूर्ण संरचना नै विगार्ने स्थिति देखिन पुग्यो । लुम्बिनी परियोजनाको मुटुमै अवस्थित पवित्र परिसरको मायादेवी मन्दिरको स्वरूपमा उक्त रुखले असर पार्ने भएपछि ठूलो पिपल रुखका जराहरू हटाएर जमिनमुनीको संरचना जोगाउने अर्थात् विग्रन नदिने नीतिमा बढेको लुम्बिनी विकास कोष निर्णय नै गरेर बढ्यो (लुम्बिनी डेभलपमेन्ट..., २००४: १७-१५)। आवश्यक सल्लाहपछि, विश्व सम्पदामा सूचीकृत भएकाले संरक्षण एवं पुनर्निर्माणका लागि संयुक्त राष्ट्रसंघ समेतको सल्लाह गरेको लुम्बिनी विकास कोषले नेपाल पुरातत्त्व विभाग र जापान बुद्धिष्ट फेडरेशनसँग सम्कौता गरेर कार्य थाल्यो । नेपाल सरकार एवं जापान बुद्धिष्ट फेडरेशनद्वारा पुरानो पिपलको रुख हटाएर उत्वनन गरि तीर्थयात्री एवं आगन्तुकहरूलाई प्राचीन मन्दिरको संरचना समेत देखिने स्थिति सिर्जना गर्ने नीति अनुरूप उत्बनन् थालि केशर शमशेरद्वारा निर्मित मन्दिरको संरचना हटाएर अशोककालिन ईंटाद्वारा निर्मित संरचनाको स्थानसम्म पुगेर अभै पुरानो संरचना समेत भएको पत्ता लगायो (कनिङघम, आचार्य र डेभिस, २०१६ : १०६-१०९; (11 Oct. 2013) । सम्राट अशोकद्वारा बुद्ध जन्मस्थल स्थानापन्न गरिएको पहिचान शिलासमेत भेटिएपछि उक्त शिलासहितको मन्दिर बनाउने, अत्यन्त महत्त्वपूर्ण पहिचान शिला अर्थात् मार्कर स्टोनलाई सड्ग्रहालयमा सुरक्षित राखेर मायादेवीको विशाल मन्दिर बनाउने वा प्राचीन संरचना देखिने गरी नेपाली मौलिक शैलीको मन्दिर बनाउने आदि कुरा उठेर भएको विवादले गर्दा लामो समय अर्थात् करिव १० वर्षसम्म मन्दिर बन्न सकेन (विडारी, १४ फेब्रोअरी २००२)। लुम्बिनीको विकास चाहेको राष्ट्रसंघद्वारा भने आवश्यक सहयोग पुच्याउने कार्य हुँदै थियो। त्यसै ऋममा १९९७ मा यूनेस्को अर्थात् शिक्षा विज्ञान तथा संस्कृति क्षेत्रमा क्रियाशिल संयुक्त राष्ट्रसंघको एक निकायद्वारा लुम्बिनीलाई विश्व साँस्कृतिक सम्पदा सूचिमा सूचीकृत गय्यो (कनिङघम, आचार्य र डेभिस, २०१६ 
: १०६)। अर्कोतिर उचित ढंगले पुनर्निर्माण गर्नका लागि वास्तुकला एवं आर्थिक वा वित्तीय समस्या वा चुनौती उत्पन्न भएको थियो। राष्ट्रिय-अन्तर्राष्ट्रिय जगत्बाट व्यापक चासो प्रकट गर्दे टीका टिप्पणी हुनेक्रम बढेपछि, २३ नोभेम्बर 9999 का दिन युवा खेलकुद तथा संस्कृति मन्त्री एवं लुम्बिनी विकास परिषदका अध्यक्ष शरद सिंह भण्डारीले एक घोषणा जारी गर्दे नेपाली जनता एवं श्री $y$ को सरकारद्वारा काँधमा काँध मिलाएर मायादेवी मन्दिर पुनस्स्थापना र संरक्षण गर्न तत्पर रहेको जानकारी दिई सम्पूर्ण जिम्मेवारी लिने घोषणा गरि उचित तिथि जुराएर शिलान्यास समेत गरेका थिए। (लुम्बिनी डेभलपमेन्ट, २००४ : १६; शर्मा, २७ मार्च २०२०)। जसबाट विवादको स्थिति आउँछ भने आफ्नो सम्पदा संरक्षण-पुनर्निर्माण गर्न नेपाल सरकार कटिबद्ध छ भन्ने सन्देश प्रवाहित भएकाले सकारात्मक अवस्थाको विकास शुरु भयो ।

उत्वननपछिको मायादेवी मन्दिर पुनर्निर्माण आफैं गर्ने प्रतिबद्धता जनाएर शिलान्यास गरिएपछि, लुम्बिनी विकास कोष यूनेस्कोसँग अनुमती लिने तर्फ लाग्यो। जापान बुद्धिष्ट फेडरेशन समेतको नीतिले गर्दा चलेको खिचातानीकै कममा गुरु योजना कार्यान्वयनलाई निरन्तरता दिएको लुम्बिनी विकास कोषद्वारा विश्व जगतकै ध्यान खिचेर संयुक्त धारणा निर्माणमा सघाउ पुगोस भनी विश्व बौद्ध सम्मेलन आयोजनाको निर्णय गरेर तयारी थाल्ने काम भयो। नेपाल सरकारको सहयोगमा गरिने सम्मेलनका लागि १९९६ नोभेम्बर ३० देखि डिसेम्बर २ सम्मको तिथि तोकेर ऐतिहासिक बनाउने नीति अनुरूप तयारी तिब्र पारेपछि, युवा खेलकुद तथा संस्कृति मन्त्री पूर्ण बहादुर खड्काको अध्यक्षतामा मुख्य तयारी समिति गठन गरियो। जसले सम्मेलनको मूल विषय "विश्व शान्तिको मुहान लुम्बिनी" निर्धारण गरेर बढेपछि सम्मेलनका अन्तमा अनुमोदन गराएर त्यही अनुरूप विकास गर्ने निश्चय पनि गरेको थियो (शर्मा, २७ मार्च २०२०)।

श्रीलंका एवं नेपालका दुइजना विद्वान्हरूबाट विषयकेन्द्रीत पेपरहरू लेखाएर प्रस्तुत गराइ सुरु गरिएको सम्मेलन उद्घाटन कार्यक्रममा स्वागत मन्तव्य व्यक्त गरेको मुख्य तयारी समितिको अध्यक्ष मन्त्री पूर्ण बहादुर खड्काबाट सम्मेलनले विश्व शान्तिको मुहान भगवान बुद्धको जन्मस्थल लुम्बिनीको महत्त्व बोध गराएर विश्व जगतको ध्यानाकर्षण गर्ने आशा र विश्वास व्यक्त गर्दे विविध कारणले दून्दू, वैमनस्यता, आतंक बढ़दै गएको विश्वमा भ्रातृत्व, भाइचारादेखि विश्वशान्ति लगायतका मानवीय सन्देशहरू प्रवाहित गर्नु नै सम्मेलनका मुलभूत उद्देश्यहरू रहेको स्पष्ट गरे (वेलकम एड्रेस, $999 \rho: y \gamma-y y$ ) । तात्कालिक युवराजधिराज एवं शाही प्रतिनिधि परिषद्का अध्यक्ष दिपेन्द्र वीर विक्रम शाहद्वारा उद्घाटन गरिएको उक्त सम्मेलनमा मूल आयोजक समितिका अध्यक्षका रूपमा सम्बोधन गरेका गिरिजाप्रसाद कोइरालाबाट संसारका शान्तिप्रेमी जनतादेखि बौद्धमार्गीहरूसम्मकै पवित्रतम तीर्थस्थल स्मारक लुम्बिनी विश्व समाजकै सम्पदा रहेको जनाउँदै सम्बन्धित संघ संस्थाहरूलाई शान्ति सम्बन्धी कुनै निर्णय लिनु परेमा अहिंसा र शान्तिका लागि उभिएका बुद्धको जन्मभूमि विश्व शान्तिको मुहान लुम्बिनीको पवित्र बगैंचामा आएर गर्ने गरौं भन्दे त्यसबाट मानवियता, अन्तर्राष्ट्रिय भ्रातृत्वका प्रतीक र शान्तिका प्रवर्तक बुद्धलाई सम्भेको वा कदर गरेको हुने स्पष्ट गरे (एड्रेस, १९९९ : ६२६४)। त्यसपछि, आफनो उद्घाटन मन्तव्य व्यक्त गरेका युवराजाधिराजबाट बुद्धले दिएका अन्तर्राष्ट्रिय शान्ति 
लगायतका ज्ञान सदा सान्दर्भिक रहेकाले बौद्ध दर्शनमा आधारित पञ्चशिल विश्व जगत्के मार्गदर्शक बनेको जनाएर लुम्बिनी विश्व जगत्कै शान्ति र प्रतिष्ठाका लागि प्रसिद्ध विश्व शान्तिको मुहान भएकाले शान्तिप्रेमी विश्व जगत्बाट लुम्बिनीको विकासमा सक्रिय सहभागिता जनाउने बढाउने आशा व्यक्त गरे (इनागुरल एड्रेश, 9999 : ६४)। उक्त सम्मेलनको शुरुदेखि अन्तसम्म सहभागिता जनाउने सहभागि प्रतिनिधि, विदेशी पाहुना, बौद्ध भिक्षु एवं संघ संस्थाका पर्यवेक्षक आदिबाट सम्मेलनको मूल विषय "विश्वशान्तिको मुहान लुम्बिनी" लाई सकारात्मक र उपयुक्त ठहय्याउँदै विश्व जगत्बाट अनुमोदन गरेर साँच्चै विश्व शान्तिको मुहानका रूपमा विकसित गर्न अनुरोध गरेको कुरा धेरैबाट सुन्न पाइएको हो। त्यसपछि अन्तिम दिन अर्थात् २ डिसेम्बर १९९६ का दिन आयोजित समापन समारोहमा विश्व बौद्ध सम्मेलनको लुम्बिनी घोषणापत्र प्रस्तुत गरेका प्रधानमन्त्री गिरिजाप्रसाद कोइरालाबाट आवश्यकता अनुरूप धन्यवाद ज्ञापन गर्दे बौद्ध मार्गीहरूको अन्तर्राष्ट्रिय समुदाय र संसारका शान्तिप्रेमी जनसमुदायहरूबाट लुम्बिनीलाई विश्वशान्तिको मुहान एवं शान्तिप्रेमी विश्व जनसमुदाय एवं बौद्धमार्गीहरूको पवित्र धार्मिक तीर्थस्थलको केन्द्र बनाउने नेपालको घोषणालाई मान्यता दिएर साकार बनाउने आशा व्यक्त गरे (प्रिजेन्टेशन अफ..., १९९९: ९७-१००)। यसप्रकार सम्पन्न गरिएको विश्व बौद्ध सम्मेलनका सहभागिदेखि अतिथिहरूसम्मबाट मायादेवी मन्दिर निर्माणबारे कुरा उठाइएकाले आयोजकद्वारा छिटोभन्दा छिटो बनाइने जवाफ दिएर थुम्थुम्याउने प्रयास गरियो। तर पनि यथार्थमा त्यो छिटै सम्भव नभएकाले २००१ मा आयोजित अन्तर्राष्ट्रिय बौद्ध सम्मेलनमा पनि कुरा उठ्यो। जसबाट लुम्बिनीको सवैभन्दा महत्त्वपूर्ण स्मारक मायादेवी मन्दिर निर्माणमा ढिलाई गर्न नहुने ठहर गरिएकाले संस्कृति मन्त्रीको जिम्मेवारीमा पुगेका बलबहादुर के.सी. ले पुरातत्त्व विभाग एवं लुम्बिनी विकास कोषलाई ठाडो आदेश दिए। त्यसपछि यूनेस्कोको अनुमती प्राप्त गरेको लुम्बिनी विकास कोषले यूनेस्कोद्वारा निर्धारित पुरातात्विक मापदण्डका मानकहरू पुरा गरेर मायादेवी मन्दिरको पुन:र्निर्माण सम्पन्न गयो। २००२ मा शुरु गरेर करिव एक वर्षको अवधिमा नेपाली शैली र नेपाली विज्ञहरूको रेखदेख एवं सुपरिवेक्षणमा निर्माण सम्पन्न गरिएको मायादेवी मन्दिरको समुद्घाटन् $\checkmark$ मे २००४ का दिन बुद्ध जयन्ती २४४६ का अवसरमा आयोजित कार्यकमका बीच तत्कालिन राजा ज्ञानेन्द्रबाट गराइएको दृश्यलाई पड्किकारले नै हेर्ने अवसर पाएको थियो ।

यसप्रकार संसारकै लाखौं मानिसहरूको धार्मिक, आध्यात्मिक तथा पर्यटकीय गन्तव्यको प्रतीकका रूपमा स्थापित वर्तमानको लुम्बिनी लामो आरोह-अवरोहको प्रतिफल हो भन्नै पर्दछ। स्वर्गका राजा इन्द्रको चित्रलता कुज्जसँग तुलना गर्न सकिने मानिएको शाक्य एवं कोलियहरूको सुन्दर उपवन-बगैंचाबाट शुरु भएर बुद्ध जन्मस्थलपछि पवित्र तीर्थस्थल भई अनेकौ प्रकोप सहेर लोपोन्मुख अवसरमा पुगेको यो महत्त्वपूर्ण स्मारक पुन: विकासपथमा बढेर विश्वशान्तिको मुहान बन्न गएको छ। विश्व जगतबाट चासो देखाइएपछि, हाल गुरुयोजना करिब पुरा भइसकेको लुम्बिनीमा कुल ३२ वटा मोनाष्ट्र, विहार र स्मारकहरू, अनुसन्धान केन्द्र आदिको निर्माण पुरा भइसकेको छ। यसैगरी केन्द्रीय नहर प्रणाली सहितको व्यवस्थित पदमार्ग अनि टेक्सी, ई रिक्सा गुड्ने सडक सहितको व्यवस्थित बसपार्कले गर्दा साँच्चै प्राकृतिक सुन्दरता र शान्तिभूमि बनेको लुम्बिनी सम्पूर्ण शान्तिकामी नागरिकहरूको उत्कृष्ट गन्तव्य बन्दै गएको छ। 


\section{उपसंहार}

नेपालको पश्चिम-दक्षिण तराइमा अवस्थित लुम्बिनीमा जन्मिएका सिद्धार्थले सांसारिक मोहमाया त्यागेर मुक्तिको खोजी गरेर पाएको ज्ञानलाई जनसमक्ष पुच्याउँदै संगठन परम्परा अगाडि बढाएका थिए। वैदिक सनातन हिन्दूहरूको समग्र दर्शन निर्देशित प्राचीन समाजमा विद्यमान प्रवृत्ति र निवृत्ति नामक दुई मार्गमध्ये साँसारिक ज्ञानको प्रतिनिधित्व गर्ने प्रवृत्ति मार्गले संसारलाई नै महत्त्वपूर्ण केन्द्र मान्दछ भने संसारलाई मित्थया मान्ने निवृत्तिमार्ग असंसारिक अर्थात् आत्मा परमात्माको चिन्तनलाई मूल ठान्दछ। समग्र हिन्दू दर्शन निर्देशित समाज भित्रैबाट विकसित बौद्ध मान्यताले निवृत्ति मार्गको प्रतिनिधित्व गरेर संसारलाई अनित्य मानि दु:खमय, कष्टमय र मायाजालको कारण ठहय्याएको छ। अनित्य अनात्मा र दु:खलाई सिद्धान्तका आधार बनाएको बौद्ध दर्शन बुद्ध, संघ र धम्म मा समर्पित भएर बुद्ध शरणम् गच्छामीको नीति अनुरूप क्रियाशिल हुँदै लोकप्रिय बनेको हो। समाजमा हिंसाजन्य यज्ञ परम्परा फैलिइरहेको अवस्थामा त्यस विरुद्ध आवाज उठाएर हिंसा नगर्ने जनाधार तयार गरेका बुद्ध वैदिक परम्पराका विरुद्ध भने कहिल्यै गएनन्। मानिसहरूको इच्छापूर्तिका लागि आफ्नो दर्शनलाई कहिल्यै प्रचार नगरेका उनले जनसमक्ष स्वर्गको ढोका खोल्ने, मोक्षप्राप्तिको उपाय बताउने आदि लोभमूलक कार्य गर्दे गरेनन्। सम्पन्न राजघरानामा जन्मिएर ऐश-आरामको जिन्दगिलाई लातमारि जड्गलको कण्टकाकिर्ण जीवन स्वीकार गरेका सिद्धार्थले धन तथा सुखको कामनै नगरी शरीरलाई अतिसय कष्ट दिने काम गर्दा प्राप्त अनुभवका आधारमा नीति वा कार्यशैली परिवर्तन गरेपछि मात्र बुद्धत्व पाएका हुन्। अत्यन्त सुखसयलमा हुर्किएर सवैजसो मानवीय सोख सयल भोगेपछि पूर्ण युवावस्थामै राजपाठ, रानी, सन्तान सबै छाडेर विरक्ती अर्थात् तपश्यापथ चुनेपछि भिक्षापात्र बोकेर माग्नेदेखि संसारलाई विश्वशान्तिको उपदेश दिंदै हिंड्ने अलौकिक र दिव्य व्यक्तित्वको स्थान पाएका उनले पापकर्ममै लिप्त-निवृत्त भएकाहरूमा समेत परिवर्तन ल्याएका प्रसड्गहरू जातक कथाका रूपमा पढ़न पाइन्छ।

वास्तवमा बुद्धले मानव जगत्लाई धर्म होइन दर्शन दिएका हुन् । तर वर्तमान जगत्ले त्यसलाई दर्शन नभनेर धर्म मान्दछ वा भन्दछ। बौद्ध दर्शनको आधार निवृत्तिमार्गको दर्शन र बुद्धको अर्थ खोज्दा पौराणिक ग्रन्थहरूकै आधार लिनु पर्दछ। विद बाट वेद र विद बाटै बुद्ध बन्दछ भन्ने पौराणिक अवधारणा विश्लेषण गर्दा विद वा वेदको अर्थ ज्ञान हुन आउने स्थितिमा बोध भएपछि मानिस बुद्ध हुने प्रस्ट भएबाट यो ज्ञान प्राप्त गर्ने जोसुकै पानि बुद्ध हुने देखिन्छ। निश्चित ज्ञान प्राप्त गर्न सक्ने जो कोही बुद्ध बन्न सक्ने प्रस्ट हुँदा हुँदै पनि गौतम बुद्धलाई मात्रै अन्तिम बुद्ध मान्ने जस्तो भ्रामक ज्ञान हामिकहाँ पाइन्छ। राजकुमारको सुखसयल भोगेर २९ वर्ष पुगेपछि प्राप्त अनुभवले गर्दा विरक्तिएर चिन्तन थालि ज्ञान प्राप्त गरि बुद्ध बन्ने मार्ग वा ज्ञान बुक्षेर गृहत्याग गरेका बुद्धले तत्कालिन परिवेश र सामाजिक परिस्थितिको विश्लेषण पछि कपिलमुनीको सांख्य दर्शन आधारित ज्ञान प्राप्ति मार्ग अंगिकार गरे। अद्वैत वेदान्तको ठिक विपरित मान्यता राख्ने र प्राचीनकालमा अत्यन्त लोकप्रिय सांख्य दर्शनलाई नास्तिक दर्शन पनि मानिन्छ। जसमा संख्या अर्थात् विज्ञानलाई बढ़ी जोड दिएका कपिल इश्वरको अस्तित्त्वमा मौन रहेका छन् । त्यसैगरी गौतम बुद्ध पनि इश्वरको अस्तित्त्वमा मौन देखिएकाले बुद्ध दर्शनलाई मूलतः कपिलको सांख्य दर्शनको लोकलयमा गरिएको व्याख्या मानेर कपिल-बुद्ध दुवैलाई नेपालका 
धर्तीपुत्र घोषणा गर्नु पर्दछ। हाम्रा समाजमा विद्यमान ऋषि परम्परा, मुनी परम्परा, पौराणिक परम्परा अनुरूप सांख्य दर्शनका प्रणेता कपिललाई कपिलमुनी र सिद्धार्थ गौतम अर्थात् बुद्धलाई शाक्यमुनी मानिएको हो । त्यसैले मुनी परम्पराका व्याख्याता र अगुवा बुद्धलाई किन गौतम बुद्ध भनियो ? गौतम भनेका को हुन् ? गौतम ऋषि वा पालकमाता गौतमी ? आदि प्रश्नको उत्तर जान्न गौतम शब्द कसरी आयो आफैंमा अनुसन्धेय छ।

प्रागऐतिहासिककालदेखि नै आफ़ै विशेष पहिचान राख्दै आएको नेपाल ऐतिहासिक-धार्मिक धरोहर, जैविक विविधता, कला, संस्कृति, धर्म, सामाजिक एकता आदिले सम्पन्न मुलुकका रूपमा चिनिन्छ। विश्वजगत्मै महानतम धर्मको स्थान प्राप्त गरेको बौद्ध दर्शन-धर्मका जन्मदाता बुद्धको जन्मस्थल लुम्बिनी महत्त्वपूर्ण तीर्थस्थलका रूपमा चिनिन्छ। जनक, भृकुटी, सीता, अरनिको आदि राष्ट्रिय विभूति जन्माउने नेपालीभूमि भगवान् शंकर अर्थात् शिवको वासस्थान पनि हो। यहींको शाक्य कोलियहरूद्वारा संरक्षित लुम्बिनी उपवनमा जन्मिएका सिद्धार्थले ऐश-आराम, सोख-सयलको जिन्दगीयुक्त वातावरणमा हुकिंदै २९ वर्ष विताउने ऋममा भोग्नु पर्ने ऐश आरामदेखि विलाशि जीवनसम्मका सम्पूर्ण कुरा हासिल गरेकै हुन्। भविष्य सम्बन्धमा गर्भाधानकै क्षणदेखि भएका ज्योतिषिय भविष्यवाणि जन्मदेखि नामाकरण संस्कारसम्मकै अवसरमा पनि दोहोरिएपछि छोरो सन्यासी जोगी हुनुलाई नराम्रो ठान्ने संस्कारमै हुर्किएका सुद्धोदनले जीवन यात्राका कुनै पनि पक्षको जानकारी नदिइकन सुख सुविधामै पालेर आमोद प्रमोदको सम्पूर्ण व्यवस्था सहितको विलाशी जीवनको रसरझुमै भुलाउने प्रयास गरे । जन्म, मृत्यू, सुख, दु:ख, संसार, अनित्य चोला आदिबारे केही थाहै नपाइ विश्वामित्र जस्ता गुरुबाट धर्मग्रन्थ, युद्ध विद्या, राजनीति समेतका शासकीय शिक्षा प्राप्त गरेका उनमा जन्म, मृत्यू, सुख, दु:ख, रोग, वैराग्य आदि मानवजगतका यथार्थ देखे जानेपछि, सोच्नै पर्ने बाध्यात्मक परिवेश उत्पन्न भयो। सम्भवत आम मानिसहरूभौै सुरुदेखि मानव जीवन जगतका नियम प्रक्रियासँग अवगत भएर सबै प्रक्रिया देख्दै भोग्दै हुर्कन पाएको भए जीवन जगत्को नियमै यस्तो हो भनी आम मानिसले ग्रहण गरेकैँ उनले पनि सामान्यिकरण गर्न सक्थे कि ? भन्ने प्रश्नको उत्तर खोज्नु पर्ने देखिन्छ।

सिद्धार्थले मानव जगतमा उपलव्ध सवै किसिमका सुखसयल, आनन्द, शान्ति, भोगविलास आदि भोग्दै $२ ९$ औं बसन्त पार गरेपछि, एक्काशि वृद्ध, विमारी-रोगी, मृतक, दु:खी, सन्यासी देखेपछि, अचम्भित तर किंकर्तव्यविमुढ स्थितिको सामना गरेका हुन्। मानव जीवन चक्रको साक्षात्कारबाट अत्यन्त दुःखी भएका उनको मन मुटु पोलेपछि थालेको चिन्तन-सोचका अन्तमा जन्म-मृत्यू, लोभ-लालच, हिंसाको चक्रबाट मानवलाई नै मुक्ति दिने उपाय खोज्ने लक्ष्य निर्धारण गरेपछि, मध्यरातमा माया-मोह-लोभ-भोगका सम्पूर्ण बन्धन चुडाली ज्ञानको खोजीमा निस्किएका हुन् । ज्ञान प्राप्तिपछिको बाँकी जीवन पनि निस्वार्थ मनले संघ परम्पराको स्थापना र विकासमै समर्पित भएर मानव कल्याणका लागि शान्ति सन्देश छर्दै विताएकाले भगवानको दर्जा पाएका उनको जन्मस्थललाई बौद्धमार्गीदेखि विश्वशान्तिप्रेमी मानव जगतसम्मले पवित्र तीर्थस्थलका रूपमा स्वकिर गरेका छन् । 
भारतीय जगत्मा प्रभाव जमाएपछि, धर्म-दर्शनका नयाँनयाँ विधा-क्षेत्रको खोजअनुसन्धान गरेका पश्चिमेली विद्वान्हरूबाट बौद्ध दर्शन र साहित्यको अध्ययन-प्रकाशन गरिदिएपछि पत्ता लगाइएको लुम्बिनीमा सम्राट अशोकको स्पष्ट अभिलेख सहितको अशोक स्तम्भ प्राप्त भएपछि थालिएको संरक्षण-सम्वर्द्धन, उत्वनन र विकास निर्माणले आजको स्थितिमा पुच्याएको हो । बौद्वकालिन परिवेशकै कल्को दिने किसिमको शान्त वातावरणमा संरक्षण विकास गर्न खोजिएको लुम्बिनी गुरुयोजना पुरा भएमा विश्व बौद्ध परिवारको भलक देखिने उत्कृष्ट स्मारक बन्नेमा कुनै शंका गर्नु पर्देन। विश्व जगत्कै बौद्ध एवं हिन्दूहरूले पवित्र स्थल मानेर विश्वशान्तिको मुहान घोषणामै सघाएको महत्त्वपूर्ण र पवित्र स्मारकको संरक्षण-विकासमा थप ध्यान पुच्याउँदै बुद्धको जीवनकथासँग जोडिएका तिलौराकोट, कुदान, निग्लिहवा, सग्रहवा, रामग्राम, देवदहजस्ता महत्त्वपूर्ण स्थलहरूको सर्किटनै बनाएर संरक्षण-प्रचार गर्दे विश्व गौरवको प्रतीक बनाउन लागि हाल्नु पर्ने आजको मूल आवशयकता हो, चेतना भया ।

\section{सन्दर्भ सामग्रीहरू}

अमृतानन्द, भिक्षु (१९९९). संक्षिप्त बुद्ध जीवनी. लुम्बिनी : अन्तर्राष्ट्रिय बौद्ध समाज । अधिकारी, सूर्यमणि (२०००). विश्व इतिहासको रूपरेखा. काठमाडौं : भुँडीपुराण प्रकाशन । आचार्य, श्रीचतुरसेन शास्त्री (१९४०). बुद्ध और बौद्ध धर्म. देहली : हिन्दी साहित्य मण्डल । आचार्य, नरेन्द्रदेव (१९४४) . बौद्ध धर्म दर्शन. दिल्ली : मोतिलाल बनारसीदास पव्लिसर्स प्राइभेट लिमिटेड । आंवेडकर (क), भीमरावजी (१९५७७। भगवान बुद्ध और उनका धम्म. मुम्बई : सिद्धार्थ महाविद्यालय प्रकाशन । आंवेडकर, बि.आर. (१९५७). दि बुद्ध एण्ड हिज धम्म. बम्बई : सिदार्थ कलेज पव्लिकेशन ।

इनागुरल एड्रेश वाइ हिज रोयल हाइनेस ऋाउनप्रिन्स दिपेन्द्र विर विक्रम शाहदेव अन १ डिसेम्बर १९६६। एड्रेश वाइ राइट अनरेवल प्राइम मिनिष्टर गिरिजाप्रसाद कोइराला अन् १ डिसेम्बर १९६द । कनिङघम, रोबिन, आचार्य, कोषप्रसाद, डेभिस, क्रिष्टोफर (२०१६). आरकियोलोजिकल डिस्कभरिज इन नेपाल्स नाटाल ल्याण्डस्केप अफ दि बुद्ध". प्रोसिडिड़ अफ २५६० औं बुद्ध जयन्ती सेरिमोनी एण्ड इनटरनेशनल बुद्धिष्ट कन्फ्रेन्स १९-२१ मे २०१६ काठमाडों एण्ड लुम्बिनी नेपाल. नेपाल : गभर्मेन्ट अफ नेपाल मिनिष्ट्रि अफ कल्चर टुरिजम एण्ड सिभिल एभिएसन एण्ड लुक्बिनी डेभलपमेन्ट ट्रस्ट, पृ. १०७-११९। क्याकल, बुक्को डयान्डो (२०१६). भगवान बुद्धका उपदेश. टोकियो जापान : कोसाइको क. लिमिटेड । गर्ज, लीला (२००६). गौतमा. इण्डिया : नेशनल बुक ट्रष्ट।

गुरुड, हर्क (१९९९). डेभलपिड “लुम्बिनी एज पिलिग्रिमेज सेन्टर अफ पिस". तुलसीराम वैद्य र प्रेम खत्री

(स.). प्रोसिडिड्गस अफ दि वर्ल्ड बुद्धिष्ट समिट लुम्बिनी नोभेम्बर ३०-डिसेम्बर २. २०१६. नेपाल:

हिजमेटेस्टीक गभर्मेन्ट अफ नेपाल एण्ड लुम्बिनी डेभलपमेन्ट ट्रष्ट. पृ. २१-४२। गुरुजी, आनन्द डव्लु. पि (१९९९). "बुद्धिष्ट फिलोसोफि एण्ड वर्ल्ड पिस" पूर्ववत् पृ. १३-२०। 
गौतम, बद्रीनारायण (जुलाई-सेप्टेम्बर २०१९). "ओरिजन एण्ड क्यारेक्टरस्टिक्स अफ एनसियन्ट नेपलिज सोसाइटी". धरमाविर (स.). कन्टेम्पोररी सोसल साइन्सेज भो. २६ नं. ३. न्यूदिल्ली : रिसर्च फाउन्डेशन इन्टरनेशनल. पृ. द१-५७।

जनरल सेक्रेटरी., (२०००). लुम्बिनी पास्ट प्रिजेण्ट एण्ड फ्यूचर उइथ दि मास्टर प्लान. इण्डया : महावोधि सोसाइटी अफ इण्डया उइथ दि कर्टसी अफ दि बुद्धिष्ट लाइब्रेरी इन सिंगापुर ।

ढकाल, दिपेन्द्रपुरुष (२००२). "टुरिजम इन बुद्धिष्ट साइटस". तुलसीराम वैद्य आदि (स.). प्रथम अन्तर्राष्ट्रिय इतिहास सम्मेलनको कार्य विवरण र कार्यपत्रहरू. काठमाडौं : नेपाल इतिहास संघ र इतिहास केन्द्रीय विभाग, त्रि.वि., पृ. २०-२६।

थेरा, पियादशि (१९५२). दि बुद्ध हिजलाइफ एण्ड टिचिड: श्रीलंका : बुद्धिष्ट पव्लिकेशन सोसाइटी कान्दे । नदिम, इशन एच. (२००९). बौद्ध गन्धार इतिहास, कला र वास्तुकला. पाकिस्तान : साँ-इ-मील प्रकाशन । नाथ, योगी नरहरी (२०१५). हिमवत्तण्ड. काठमाडौं : नई प्रकाशन ।

नेपाल सरकार (१९९१). लुम्बिनी विकास कोष ऐन २०४२ (पहिलो सोधन २०४६). काठमाडौं : कानून न्याय तथा संसदीय मामिला मन्त्रालय ।

पाण्डे, रामनिवास र रेग्मी, दिनेशचन्द्र (१९९७). नेपालको पौराणिक इतिहास. काठमाडौं : नेपाल र एशियाली अनुसन्धान केन्द्र त्रि.वि. ।

पाण्डे, रामनिवास (१९६\%). "आरकियोलोजिकल रिमाइन्स अफ लुम्बिनीज दि वर्थ पेलेस अफ लर्ड बुद्ध". कन्ट्रिव्यूसन्स टु नेपलिज स्टडिज भो. १२ नं. ३. कीर्तिपुर : सेन्टर फर नेपाल एण्ड एशियन स्टडिज टि. यू. पृ. ห१-६२।

पाण्डे, रामनिवास (१९९५). "दि बर्थ पेलेस अफ लर्ड बुद्ध" यूनेस्को दि सिल्क रोड्स : रोडस अफ डायलग बुद्धिष्ट रुट एक्सपेडेसन नेपलिज लिग १९९५. पृ. ३७-४३।

पाण्डे, रामनिवास (४ मे २००४). "आरकियोलोजिकल रिमाइन्स अफ लुम्बिनी : दि वर्थ पेलेस अफ लर्ड बुद्ध". वशन्त विडारी आदि (स.). लुम्बिनी इयर १० नं. ११. लुम्बनी नेपाल : इन्टरनेशनल बुद्धिष्ट सोसाइटी.

पृ. ३४-४३।

प्रधान, भुवनलाल (१९६६). नेपाल बौद्ध दर्शन. काठमाडौं : नेपाल प्रज्ञा प्रतिष्ठान । प्रिजेन्टेशन अफ दि लुम्बिनी डिक्लेरेशन अफ दि वर्ल्ड बुद्धिष्ट समिट लुम्बिनी नेपाल अन २ डिसेम्बर १९६द। बज्राचार्य, लोकदर्शन (नो. डि. २००४). "लुम्बिनीबाट बहुआयामिक लाभ हासिल गर्न सक्नुपछ". कुमार रज्जित (स.). उपदिशा निर्देश मासिक. काठमाडौं : मधुकर अधिकारी. पृ. १६-१७।

बिडारी, बसन्त (१९९५). "कपिलवस्तु दि एनशियन्ट शाक्य किड्गडडम अफ नेपाल". यूनेस्को दि सिल्करोड्स : रोड्स अफ डायलग बुद्धिष्ट रुट एक्सपेडेसन नेपलिज लिग १९९६. पृ. ४४४-७३।

बिडारी, बसन्त (२०००). "दि नेटिभिटी ट्री अफ प्रिन्स सिद्धार्थ”. उपाली रुपा सिडधे (स.) दि महाबोधि भो. १०६-१०६. इण्डिया : महाबोधि सोसाइटी अफ इण्डिया. पृ. १६-२९। 
बिडारी, बसन्त (२००३). "कपिलवस्तु जिल्लाका केही ऐतिहासिक तथा पुरातात्विक स्थलहरू". तुलसीराम वैद्य आदि (स.). प्रथम अन्तर्राष्ट्रिय इतिहास सम्मेलनको कार्य विवरण र कार्यपत्रहरू. काठमाडौं : नेपाल इतिहास संघ र इतिहास केन्द्रीय विभाग त्रि.वि., पृ. पू द-७२।

महर्जन, बसन्त (२००४). लुम्बिनी ऐतिहासिक तथा पुरातात्विक अध्ययन. काठमाडौं : बसामी डट कम । महास्थविर, भिक्षु बिमलानन्द (२००३). त्रिरत्न बन्दना और बौद्ध शिशशु बोध. लुम्बिनी नेपाल : भिक्षु बिमलानन्द महास्थविर नेपाल बुद्ध विहार ।

महाथेरा, भेनेरेवल नारश (१९९५). दि बुद्ध एण्ड हिज टिचिड्स. ताइवान : दि कर्पोरेट बडी अफ दि बुद्ध एजुकेशनल फाउण्डेशन ।

मिश्र, तारानन्द (१९७६). दि लोकेशन अफ कपिलवस्तु. काठमाडौं : लुम्बिनी विकास समिति । रकहिल, डब्लु. उडविली (१६द४). लाइफ अफ दि बुद्ध. लण्डन : टूबनर एण्ड क. लुडगेट हिल। रिजाल, बाबुकृष्ण (१९७९). आरकियोलोजिकल रिमाइन्स अफ कपिलवस्तु, लुम्बिनी, देवदह काठमाडौं : एजुकेशनल इन्टरप्राइजेज ।

रिजाल, बाबुकृष्ण (१९५३). आरकियोलोजिकल एक्टिभिटिज इन लुम्बिनी. काठमाडौं : लुम्बिनी डेभलपमेन्ट कमिटि ।

रिजाल, बाबुकृष्ण (१९९६). हन्ड्रेज इअर्स अफ आरकियोलोजिकल रिसर्च इन लुम्बिनी कपिलवस्तु एण्ड देवदह. काठमाडौं : एस. के. इन्टरनेशनल पव्लिसिड्र हाउस ।

लामोटे, इटिनी (१९६४) "दि बुद्ध हिज टिचिड एण्ड हिज संघ". हेनिज विचट एण्ड रिचर्ड गोमत्रीच (इडि.). दि वर्ल्ड अफ बुद्धिज्म बुद्धिष्ट मङ्कस एण्ड नन्स इन सोसाइटी एण्ड कल्चर. लण्डन : थेम्स एण्ड हडसन एलडिटी. पृ. ४१-४७।

लुम्बिनी डेभलपमेन्ट ट्रस्ट, (२००४). इन्ट्रोड्यूसिङ लुम्बिनी दि फाउन्टेन अफ वर्ल्ड पिस. लुम्बिनी : लुम्बिनी डेभलपमेन्ट ट्रस्ट ।

वर्ल्ड बुद्धिष्ट समिट, लुम्बिनी म्यागजिन फर वर्ल्ड बुद्धिष्ट समिट नोभेम्बर ३० - डिसेम्बर २- १९९६. लुम्बिनी : दाश ।

वेलकम एड्रेश वाई हनरेवल मिनिष्टर पूर्णबहादुर खड्का अन १ डिसेम्बर १९९५ । सांकृत्यायन, राहुल (१९४५). बुद्ध और बौद्ध धर्म. देहली : हिन्दी साहित्य मण्डल। सुवेदी, राजाराम (२००४). नेपालको तथ्य इतिहास. ललितपुर : साका प्रकाशन । सोलंखे, ए. एच (२०१७). गौतमा द बुद्ध सन अफ अर्थ. धनन्जय चभवान (सं.)( वासिङटन : परियत्ती प्रेश । शाक्य, बुद्धाचार्य (मे. २००४). "भगवान बुद्धको जन्मस्थल लुम्बिनी एक अध्ययन". हरिष्चन्द्रलाल सिंह आदि (स.). लुम्बिनी इअर १० न) ११. लुम्बिनी : इन्टरनेशनल बुद्धिष्ट सोसाइटी। शाक्य, बिमलबहादुर (9९९५). "अ ब्रिफ डिस्कसन अन लुम्बिनी दि स्टेट अफ दि आर्ट". यूनेस्को दि सिल्क रोड्स : रोडस अफ डायलग बुद्धिष्ट रुट एक्सपेडेसन नेपलिज लिग १९९२. पृ. २९-३२। 
शाक्य "त्रिशुली", धर्मरत्न (सं.) (२००४). भिक्षु विमलानन्द महास्थविरको जीवनी. लुम्बिनी : धर्मोदय समिति राजकीय बुद्ध बिहार ।

हुई, भिक्षु दिड (२०००). “कपिलवस्तु, लुम्बिनी एण्ड रामग्राम रेकर्डस अफ चाइनीज ट्राभलर्स". डि. रेवथा थेरो आदि (स.). दि महाबोधि भो. १०६-१०६. इण्डिया : महाबोधि सोसाइटी अफ इण्डया. पृ. ११-१७। क्षेत्री, गणेश र खतिवडा, सोमप्रसाद (१९९७). हिन्दू समाज र धर्म. विराटनगर : शिवा प्रकाशन ।

\section{अन्तर्वार्ताहरू}

बज्राचार्य, लोकदर्शन. लुम्बिनी विकास समितिको प्रथम अध्यक्ष र बौद्ध दर्शनको विकास संरक्षणमा सक्रिय व्यक्तित्वसँग ३१ मार्च १९९९ का दिन कोरियन मन्दिर लुम्बिनीमा ।

बिडारी, बशन्त. प्रमुख पुरातत्त्वविद् लुम्बिनी विकास कोष एवं लुम्बिनी कपिलवस्तु आदिका अध्येतासँग १४ फेब्रोअरी २००२ का दिन लुम्बिनी विकास कोष लुम्बिनीमा ।

बैध, तुलसीराम त्रि.वि. इतिहास विभागका अवकाश प्राप्त प्राध्यापक एवं लुम्बिनी बौद्ध विश्वविद्यालयका संस्थापक उपकुलपतिसँग २१ फेब्रोअरी २०२० का दिन सानेपा ललितपुरमा ।

रिजाल, बाबुकृष्ण. लुम्बिनी-कपिलवस्तु उत्वननमा लामो अनुभव बटुलेका पुरातत्त्वविद्सँग ३० मार्च १९९९ का दिन कोरियन मन्दिर लुम्बिनीमा ।

सिंह, गणेशमान. नेपाली राजनीतिका सर्बोच्च नेतासँग जनवरी १९६द को घमाइलो दिन लुम्बिनी भ्रमणका अवसरमा बताएका कुरा

सुबेदी, राजाराम. अबकाश प्राप्त प्राध्यापक इतिहास त्रि.वि. सँग १४ मार्च २०२० मा गरेको टेलिफोन वार्ता । शर्मा, बिमलकुमार. लुम्बिनी विज्ञ एवं लुम्बिनी विकास कोषका भूतपूर्व सदस्यसचिवसंग २७ मार्च २०२० दिन गरेको टेलिफोन वार्ता ।

शाक्य, छत्रराज. लुम्बिनी विकास कोषका कोषाध्यक्षसँग ३० मार्च १९९९ का दिन कोरियन मन्दिर लुम्बिनीमा । वेव साइटहरू

bodhitv.tv.article>.

dro.dur.ac.uk.

ia801600.us.archive.org.

https://drambedkarbooks. files. world press.com.

http://www.malipa.gov.np./wp.content uploads/2018/02/

लुम्बिनी विकास कोष ऐन २०४२.उमा ।

Durham Research online (11 Oct. 2013). 